\title{
Emerging Markets Portfolio Creating a Latin American Portfolio Peruvian Case Study
}

\author{
Edmundo R. Lizarzaburu, Julio Quispe Salguero \\ ESAN University, Lima, Peru \\ Renzo Berrocal \\ Thunderbird University, Phoenix, US
}

\begin{abstract}
The case study seeks to identify the most important issues encountered in developing a new portfolio in a Latin America country, exploring several alternatives which include not only stock and sovereign bonds but also more sophisticate products such as American Depositary Receipt (ADR) or Exchange Traded Fund (ETF) from emerging countries, and determine what are the risks involved in the process following not only Basil III standards, but also the local best practice recommend by the local regulators. The study at the beginning used historical information (normal distribution formulas) of several equities and bonds $(n=142)$ and then selected five Peruvian instruments (one of this involved at least 25 equities, $N=5, n=30$ ) and then other 30 (one of this include an ETF, $N=30, n=$ 55) in order to determine the best return and risk combination for an emerging market portfolio. Besides, the additional objective is to examine and introduce the reader in some statistics formulas used in finance and risk management. Senior management must evaluate the issues associated with the new portfolio and strategy developed.
\end{abstract}

Keywords: portfolio theory, sovereign bonds, shares, ADRs, emerging markets, financial instruments

\section{Introduction}

In the summer of 2011, Gabriela and Rosa were looking for a summer internship in New York City, after completing their first master degree study year in the United States. These were difficult times (June and July of 2011) because of the subprime mortgage crisis, while investment banks Lehman Brothers (in September, 2008) and Bear Stearns (in March 2008) had ceased operating in the international financial market. Regulatory changes and the economic stimulus from the United States government to its own financial system created sub-optimal conditions in the New York, Chicago, Tokyo, and London contract and investment financial markets. Mishkin (1996) defined a financial crisis as an alteration of financial markets where adverse selection and moral risks appear significantly, and financial markets are no longer to be the efficient funds channel towards the loci offering the best productive investment opportunities.

Also, these were times when emerging economies started to emerge as a clear specific option in the global

Edmundo R. Lizarzaburu Bolaños, Eng., GMBA Department, ESAN University, GFI del Peru SAC.

Julio Quispe Salguero, MBA, Finance Department, ESAN University.

Renzo Berrocal, student, GMBA Department, Thunderbird University.

Correspondence concerning this article should be addressed to Edmundo R. Lizarzaburu Bolaños, Alonso de Molina1652, Monterrico Surco, Lima 33, Peru. E-mail: elizarzaburu@esan.edu.pe. 
economy. Not just the BRICS (Brazil, Russia, India, China, and South Africa), but also countries including Colombia, Chile, Turkey, and Peru became interesting destinations for investing in financial assets, both for the short term (exchange rate or interest rate) and for the long term (bonds or stock). Stock exchanges in those countries, their "stable" exchange rate and so-called "sovereign" government debt provided attractive options for investors, in view of their credit ratings' likely improvement.

\section{A Literature Review on Portfolio Processes}

Lane (1993) identified four necessary conditions for financial markets to enforce effective discipline. The first is an open and free market. Governments should follow the same market rules as any other public or private agent. Interest rates and insurance premiums paid by governments should reflect their solvency, to prevent situations of privilege characterized by artificially low interest rates or unlimited access to credits.

The second condition concerns transparency. It requires high quality budget financial data regarding government transactions and the involved agents, whether borrowers, lenders, or intermediaries.

Thirdly, market discipline forbids governments from accepting sub-central government debt ("no-bail-out” rule).

Finally, borrowers should be able to react to increases in interest rates or risk premiums (spreads) by reducing their demand for credit or debt issuances.

Kopits (2001, p. 15) hold that "transparency leads to successful fiscal policy, for the design of both rule-based and discretional policies".

Liquidity has been defined as "the ability to rapidly and cheaply transact large amounts of a given asset at any time” (Harris, 2003, p. 394), or the possibility of buying and selling an unlimited amount of a given stock (Lee, Petroni, \& Shen, 2006).

In 1952, Harry M. Markowitz published a seminal research paper on Modern Portfolio Theory. He started by describing an individual or institutional investor with a given amount of money to invest at a given time for a certain period (the holding period). At the end of the period, the investor sells its holdings and then consumes or reinvests the proceeds or both (Sharpe, 1990).

Markowtz' model assumes that the investors' rational behavior when making decisions and choosing among investment instruments. Consequently, they will try to identify the optimum risk and performance relationship among the instruments comprised in the portfolio, as well as the amount to invest on each such component, so as to maximize returns without accepting an excessively high risk, thus meeting their specific interests and needs.

The Efficient Markets Theory is based on the Random Walk Theory. A random walk is that where future steps or directions cannot be forecast on the basis of past actions. When applying the term to capital markets, it means asset movements may not be predicted.

Minimum Variance Portfolio, in this Portfolio, the change in risk for an investment equals zero. Its main feature is that it "offers investors the minimum available risk for a set of assets that may make up an investment portfolio. To reach that portfolio, diversification is maximized and, consequently, a combination is achieved with the lowest risk level” (Rodríguez, 2005).

Optimum Portfolio, any of the portfolios found along the portfolio efficiency frontier, on the tangent point 
with the Capital Markets Curve (CMC) ${ }^{1}$. The process proposed by Black (1972) and Merton (1973) concerned about an optimum portfolio to be identified by maximizing the slope of the curve linking the risk-free returns point and the efficiency frontier. When this maximum value is reached, the curve becomes the Capital Markets Curve.

\section{Capital Markets in Latin America and Peru}

Presently in Latin America, the stock exchanges of Peru (Bolsa de Valores de Lima-BVL), Chile (Bolsa de Comercio de Santiago_-BCS), and Colombia (Bolsa de Valores de Colombia—BVC) are coming together in the so-called Integrated Latin American Market (Mercado Integrado Latinoamericano-MILA) to transact stocks in a single market. Operations started in May 2011. These stock exchanges, according to the World Federation of Exchanges, rank among the most profitable worldwide. The purpose of the merger project, following integration and merger trends as in London and Toronto, or New York and Frankfurt, is to provide better conditions for investors in each market.

This integration will create Latin America's first largest stock market by the number of issuers, the second largest by the stock capitalization and the third by volume of trade. Remarkably, integrating the three stock exchanges will allow investors to create more diversified portfolios in more liquid markets. Issuers will benefit from better conditions for raising capital while commission takers and intermediaries will be able to create new products and expand the frontiers of their business, all under the oversight of local regulators.

Diversification will be geographic and by industry. The Peruvian, Colombian, and Chilean stock markets are present in various industries that have a potential for complementing each other. Peru's market is mainly focused on metals, including precious gold and silver, as well as zinc, and features major mining companies like Buenaventura, Hoschild, Volcan, and Milpo; the energy and oil industries are strong players in the Colombian market, including Ecopetrol, Pacific Rubiales, ISA, and Colinversiones, as well as financial organizations such as Bancolombia and Corficolombiana. The retail and financial industries have a strong presence in the Chilean market, including companies such as Falabella and Cencosud.

\section{The Designed Portfolio}

This portfolio aims at creating a framework for reviewing the present potential of the Peruvian market to act efficiently in a developed capital market. The rationale behind the creation of this investment portfolio includes participation in traditional asset classes: fixed income and equity, in addition to the Exchange Traded Fund (ETF), which the researchers considered that, a stock market enhancer because of its liquidity peculiarities.

\section{Instrument Selection}

We describe below the five instruments used in the simulation used to create a proxy for a simplified efficient investment curve.

The first instrument reviewed for this investment portfolio is Peru's sovereign fund with maturity May 5, 2015 (see Figure 1). This bond carries an outstanding debt stock worth PEN 1.586 billion Nuevos Soles and was issued on May 5, 2005, at an original 9.91\% coupon rate.

At the end of the second half of 2011, holders (see Figure 2) of the 2015 sovereign bond were distributed

\footnotetext{
1 Vélez Pareja, I. Decisiones empresariales bajo riesgo e incertidumbre [Business Decisions Under Risk and Uncertain Conditions] Editorial Norma, 2003.
} 
as follows, pursuant to the data published by the Ministry of Economy and Finance of Peru.

\begin{tabular}{|c|c|c|}
\hline $\begin{array}{l}\text { SECUR I TY } \\
\text { PERU B DESCRERANO } \\
\text { PERUGB9.91 05/15 }\end{array}$ & $\begin{array}{l}\mathbf{L N}_{116.561 / 116.926} \\
\end{array}$ & $\begin{array}{l}\text { ge } 1 / 1 \\
94 / 4.84) \text { LCPR }\end{array}$ \\
\hline ISSUER INFORMATION & IDENTIFIERS & i) Additional Sec Info \\
\hline Name PERU BONO SOBERANO & ISIN $\quad$ PEP01000CX67 & D ALLQ \\
\hline Type Sovereign & SB05MAY15 & 3) Corporate Actions \\
\hline Market of Issue Domestic & BB Number ED9277697 & 4) Ratings \\
\hline SECURITY INFORMATION & RATINGS & 9 Custom Notes \\
\hline Country PE $\quad$ Currency PEN & Moody's & (4) Identifiers \\
\hline Collateral Type Sr Unsecured & $\mathrm{BBB}+$ & 7) Sec. Specific News \\
\hline Calc Typ(1275)PERUVIAN GOVT BOND & Fitch & 8 Issuer Information \\
\hline 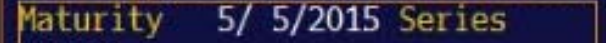 & DBRS $\quad$ BBBL & 9) Pricing Sources \\
\hline NORMAL & ISSUE SIZE & 10 Related Securities \\
\hline Coupon & Amt Issued/Outstanding & \\
\hline ACT $/ 360$ & PEN $1,586,627.00(M) \lambda$ & \\
\hline Announcement Dt 5/5/05 & $1,586,627.00(M)$ & \\
\hline Int. Accrual Dt 5/ 5/05 & Min Piece/Increment & \\
\hline 1st Settle Date 5/ 5/05 & $1,000.00 / \quad 1,000.00$ & \\
\hline 1st Coupon Date $11 / 5 / 05$ & Par Amount $1,000.00$ & \\
\hline Iss $\mathrm{Pr} 100.0000$ & BOOK RUNNER/EXCHANGE & \\
\hline NO PROSPECTUS & LIMA & 66) Send as Attachment \\
\hline
\end{tabular}

Figure 1. Local currency denominated sovereign bond (2015); Source: Bloomberg.

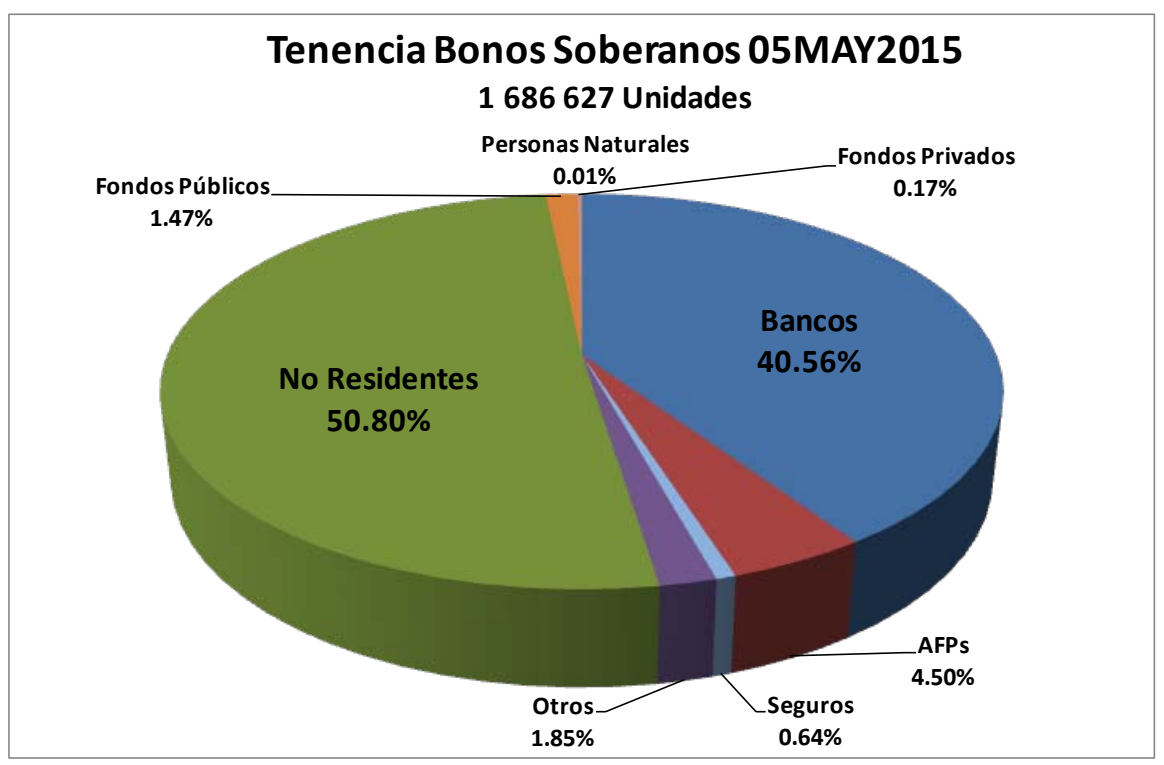

Figure 2. Sovereign bond holders (May 5, 2015)-as of June 2011.

The pie chart shows non-residents are the main creditors of the Peruvian government's bonds due in 2005. Their share reaches 50.8\%. Peruvian banks follow at $40.6 \%$. The rationality underlying the breakdown of bond holdings is the need for foreign agents to hold paper bearing returns in local currency (Nuevo Sol) to achieve a return on funds held by non-domiciled agents in Peru with two main characteristics: a market with acceptably liquid trading and the absence of withdrawals on capital earnings' income tax. 


\begin{tabular}{|c|c|c|}
\hline $\begin{array}{l}\text { SECUR I TY DESCRIPT } \\
\text { PERU B SOBERANO PERUGB } 6.908 / 37\end{array}$ & \multicolumn{2}{|c|}{$\begin{array}{l}\text { Page } 1 / 1 \\
(6.40 / 6.30) \text { LCPR }\end{array}$} \\
\hline ISSUER INFORMATION & IDENIIFIERS & 1) Additional Sec Info \\
\hline Name PERU BONO SOBERANO & ISIN $\quad$ PEP01000C2Z1 & D ALLQ \\
\hline Type Sovereign & Peru $\quad$ SB12AG037 & 3) Corporate Actions \\
\hline Market of Issue Domestic & BB Number EG6650006 & (4) Ratings \\
\hline SECURITY INFORMATION & RATINGS & (9) Custom Notes \\
\hline Country PE $\quad$ Currency PEN & Moody's & Q Identifiers \\
\hline Collateral Type Sr Unsecured & Fitch & 7) Fees/Restrictions \\
\hline Calc Typ(1275)PERUVIAN GOVT BOND & DBRS & 8 Sec. Specific NewS \\
\hline Maturity $8 / 12 / 2037$ Series & Composite & 9) Involved Parties \\
\hline NORMAL & ISSUE SIZE & 10 Issuer Information \\
\hline $6.9 \quad$ Fixed & Amt Issued/Outstanding & 11) Pricing Sources \\
\hline S/A $\quad$ ACT $/ 360$ & PEN $\quad 4,750,000.00(\mathrm{M}) /$ & 12) Related Securities \\
\hline Announcement Dt $7 / 19 / 07$ & PEN $4,750,000.00(\mathrm{M})$ & \\
\hline Int. Accrual Dt 7/26/07 & Min Piece/Increment & \\
\hline 1st Settle Date 7/26/07 & $1,000.00 / \quad 1,000.00$ & \\
\hline 1st Coupon Date $2 / 12 / 08$ & Par Amount $\quad 1,000.00$ & \\
\hline Iss $\mathrm{Pr} \quad 100.0000$ & BOOK RUNNER/EXCHANGE & \\
\hline & CITI & \\
\hline NO PROSPECTUS & LIMA & 66) Send as Attachment \\
\hline
\end{tabular}

Figure 3. Local currency-denominated sovereign bonds (2037); Source: Bloomberg.

The second instrument under consideration for our portfolio model for Peru is the sovereign bond with maturity date August 12, 2037 (see Figure 3).

Compared with the previous bond, this is one of the longest-term available holdings in the Peruvian yield curve. This characteristic allows adopting more aggressive strategies for portfolio investments.

The bond was issued on July 26, 2007 and to date 4.75 billion Nuevos Soles have still been outstanding. The original coupon rate was $6.9 \%$.

At the end of the second half of 2011, sovereign 2037 (see Figure 4) bond holdings were distributed as follows, as shown by data from the Ministry of Economy and Finance.

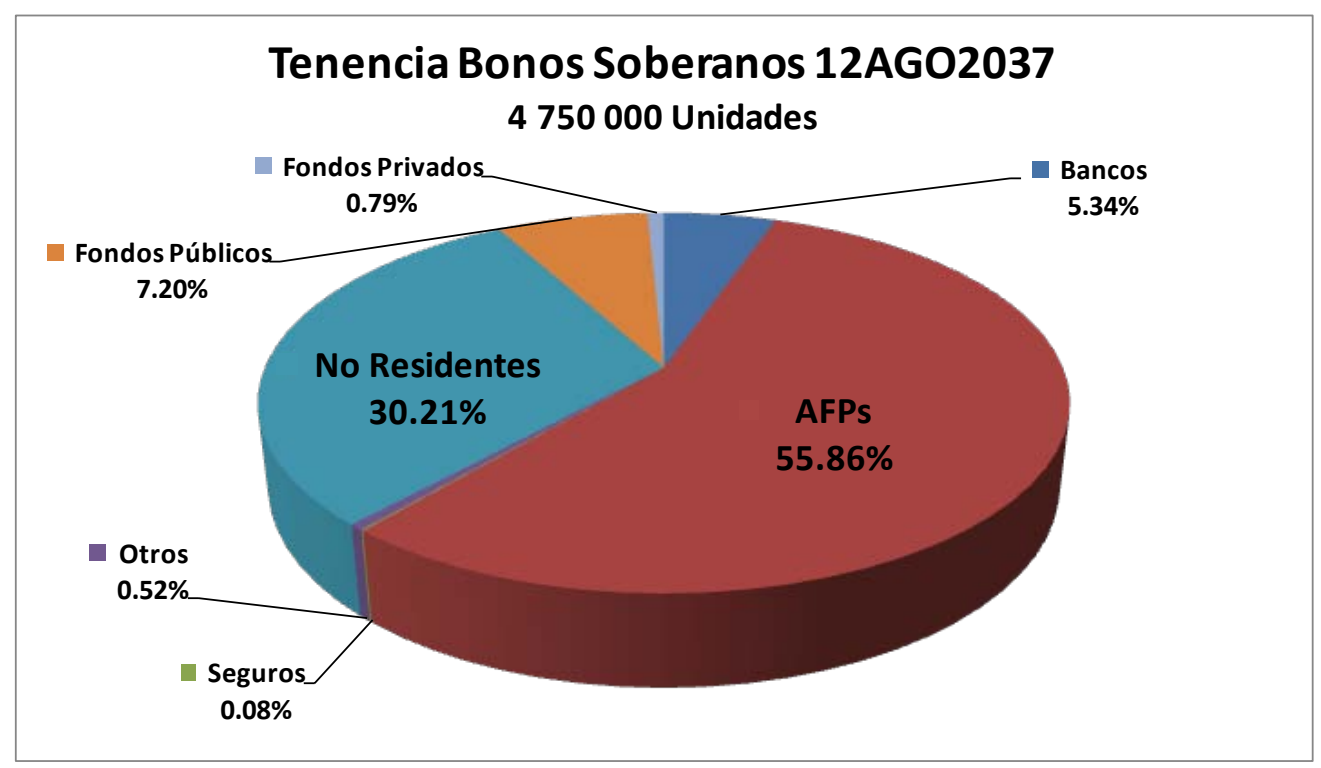

Figure 4. Sovereign bond holdings, August 12, 2037-as of June 2011.

The main holders of the Peruvian government 2037 bond are Peruvian Private Pension Funds with 55.86\% 
share. Non-resident investors rank next, with $30.21 \%$ share. The rest of the issue is split among other Peruvian institutional investors.

The investment rationale behind the 2037 bonds is not directly linked to bond face yields because of the carry trade. Rather, the rationale for holding these bonds combines the above factor and a bet on an improvement in Peru's credit rating, and a more aggressive investment strategy focusing on the bond's duration.

The third financial instrument under review is Peru's Exchange Traded Fund (ETF)—EPU (see Figure 5). Its nature, creation, redemption, administrator, the reasons why it was created, and the advantages it provides to the investors are explained below.

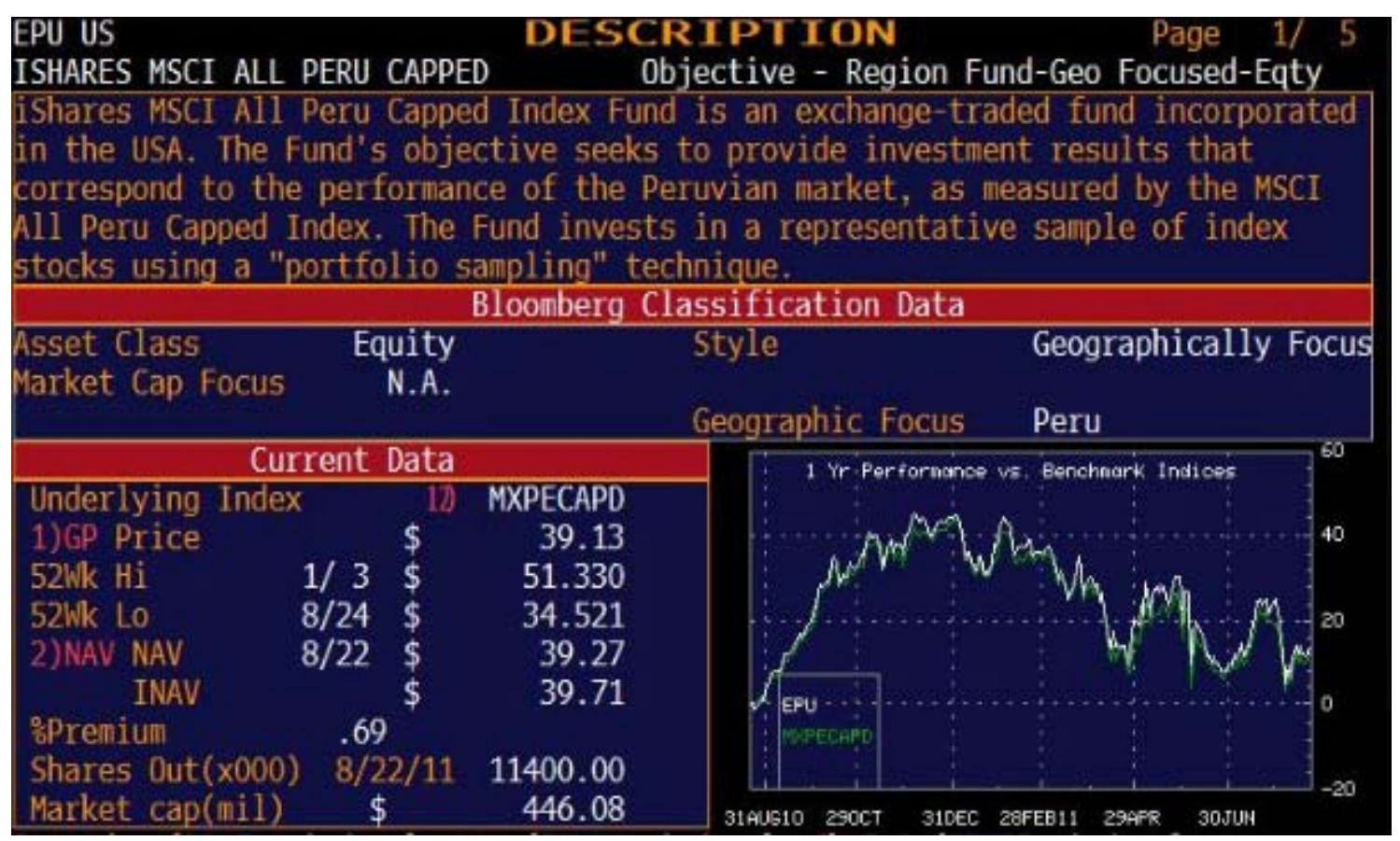

Figure 5. ISHARES MCSI details.

Peru's EPU (Peru's ETF ${ }^{2}$ ) is a fund aiming at replicating the behavior of the Peruvian equity market. Its outstanding USD 446 million meets kind-in creation and kind-in redemption criteria. In other words, any sophisticated, IT-capable brokerage can create and liquidate EPUs after registering with the corresponding administration fund, making EPU more liquid efficient than any other instrument reviewed for this portfolio.

The first significant characteristic of EPU is its objective to replicate exclusively Peru's equity market. The chart below (see Figure 6) shows a 99.96\% concentration on stocks.

By sectors, mining accounts for $52.98 \%$ of holdings, reflecting the importance of the mining industry in Peruvian exports and the Growth Domestic Product. Other significant sectors are banking (16\%) and food (7\%). As regards concentration of stocks, Buenaventura and Banco de Crédito (Credicorp) fill significant EPU positions, at $17.37 \%$ and $13.567 \%$, respectively.

The fourth selected instrument is Banco de Crédito del Perú's ADRs (see Figure 7), one of the most

\footnotetext{
${ }^{2}$ Retrieved from http://www.us.ishares.com/product_info/fund/distributions/EPU.htm.
} 
significant stocks in Peru's exchange market, where they are highly traded.

These ADRs represent a wide range of financial products and account for a relatively large share of the local market's total capitalization.

\begin{tabular}{|c|c|c|c|c|}
\hline ISHARES MSCI ALL PERU $C$ & APPED & Objective - Region F & id-Geo Focus & Eqty \\
\hline Asset Allocation as of & $7 / 29 / 11$ & Top 10 Holdings $7 / 29 / 11$ & Position & Net \\
\hline Government & $.00 \div$ & Cia de Minas Buenavent & 2159319 & 17.372 \\
\hline Corporate & $.00 \%$ & Credicorp Ltd & 706664 & 13.567 \\
\hline Mortgage. & $.00 \%$ & Southern Copper Corp & 1775544 & 11.919 \\
\hline Preferred & $.00 \%$ & Alicorp SA & 12356327 & 5.294 \\
\hline Municipal & $.00 \%$ & Minsur SA & 17228276 & 4.760 \\
\hline Equity & $99.96^{\circ}$ & Sociedad Minera Cerro & 510403 & 4.453 \\
\hline Cash and 0ther & $.04 \%$ & Nolcan Cia Minera SAA & 19123334 & 4.392 \\
\hline & & Hochschild Mining PLC & 2795110 & 4.325 \\
\hline sector/Geo Allocation & $7 / 29 / 11$ & Grana y Montero SA & 9151649 & 3.973 \\
\hline Mining & 52.98 & Intergroup Financial $S$ & 664723 & 3.497 \\
\hline Banks & 16.00 & 5) $M H D$ & & \\
\hline Food & 7.01 & Portfolio St & istics & \\
\hline Holding Companies-Diver: & 53.97 & Top 10 HIdgs $\%$ Port 7 & 55 Avg P/E & 10.86 \\
\hline Electric & 3.55 & Median Market Cap & BLN Avg $\mathrm{P} / \mathrm{C}$ & 10.20 \\
\hline Building Materials & 3.54 & Avg wtd Mkt Cap & BLN Avg $\mathrm{P} / \mathrm{S}$ & .91 \\
\hline Peru & 86.78 & Avg Div Yield & 98 Avg $\mathrm{P} / \mathrm{B}$ & 2.89 \\
\hline U.S. & 11.92 & & & \\
\hline Ireland & 1.26 & Creation & Jnit & \\
\hline & & Fstimated Cach & otal Cash & 9150.87 \\
\hline
\end{tabular}

Figure 6. ISHARES MCSI breakdown; Source: Bloomberg.

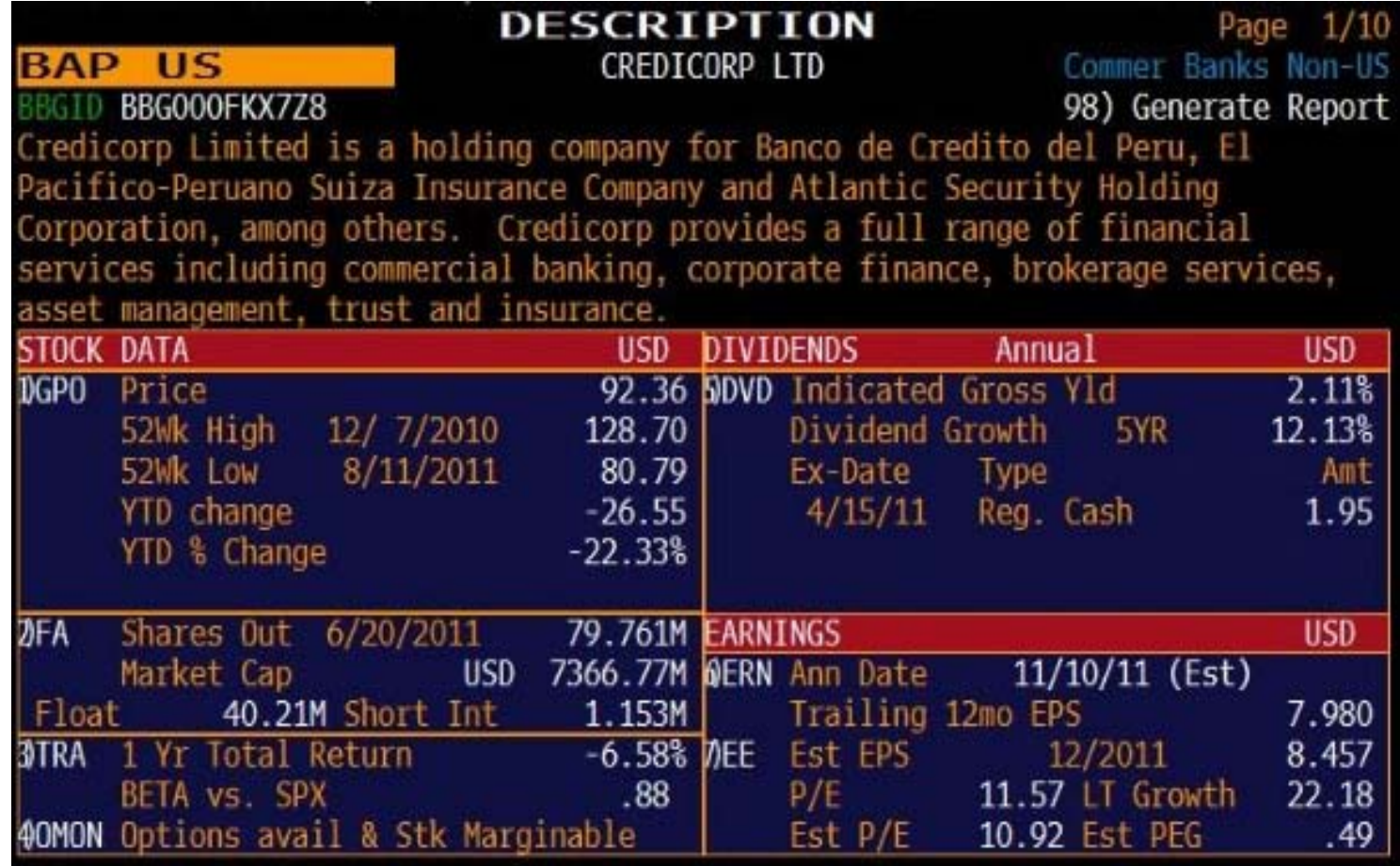

Figure 7. Banco de Crédito del Perú’s ADRs.

The authors chose to review Banco de Crédito del Peru's ADRs for this portfolio to include a market 
efficiency criterion as a characteristic of this portfolio's instrument. They are traded in US dollars. A subsequent section examines the implications of exchange rate risk, and the need to ensure a uniform and simplified yield in local currency. As this analysis was being prepared (August 23, 2011), Banco de Crédito's market value reached 7.366 billion, and its floating stock (ADRs) was worth 79.76 million.

The fifth and last instrument under review is Compañía de Minas Buenaventura (see Figure 8), also traded as New York market ADRs. For the same reasons as BAP, it is a major instrument in Peru's stock market.

Buenaventura is a Peruvian mining holding corporation with shares in other major local mining conglomerates, though the opposite is not true. Thus, it is a fully locally-owned company focusing on gold exploitation.

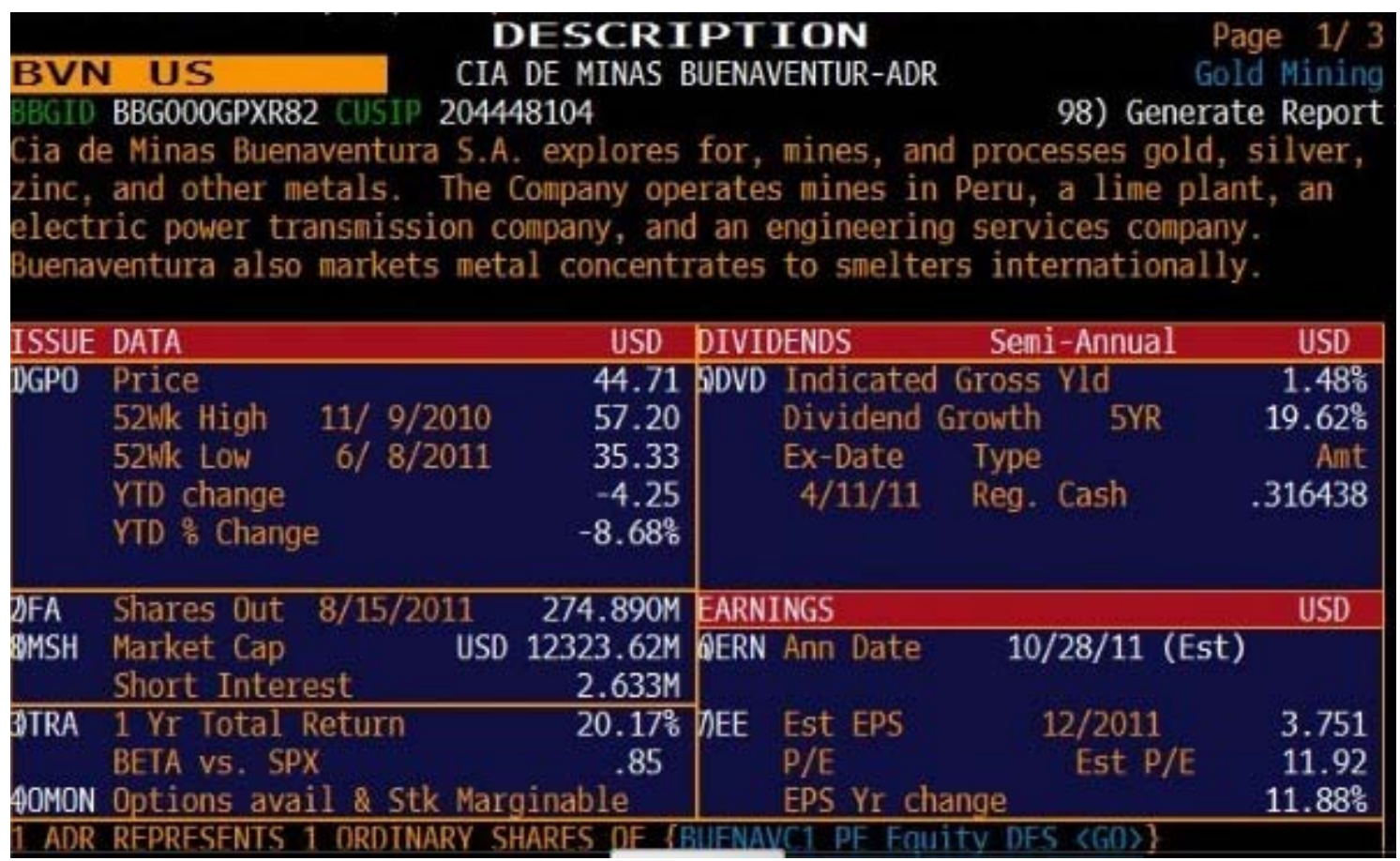

Figure 8. Compañía de Minas Buenaventura’s ADRs.

As of the date for this analysis (August 23, 2011), Buenaventura's ADRs market value reached USD12.323 billion distributed among 274.9 million shares.

Having profiled the five instruments chosen for modeling, the authors now describe the individual and collective statistical peculiarities of these stocks. This choice was made for reasons of convenience and designed by both Rosa and Gabriela, who sought to create highly diversified portfolio comprised of innovative instruments from emerging markets.

\section{Variance and Co-variance Matrix}

The price sampling of the selected instruments starts on July 1, 2010 and ends on August 23, 2011. Time series data include daily percent price changes for each of the financial assets so as to meet the two following conditions of cancelling possible spurious relationships and root units within each analysis variable, and secondly, providing a more intuitive content to daily variations in the form of capital gains/losses.

As is already mentioned, the selected instruments include:

- Cía Minera Buenaventura ADR (code BVN); 
- Credicorp (code BAP);

- ISHARES Instrument (EPU);

- Peruvian Government Sovereign Bonds (code S2015);

- Peruvian Government Sovereign Bonds (code S2037).

The authors present the below graphs showing the evolution over time of the daily percent (see figure 9) fluctuations of the financial instruments under review.

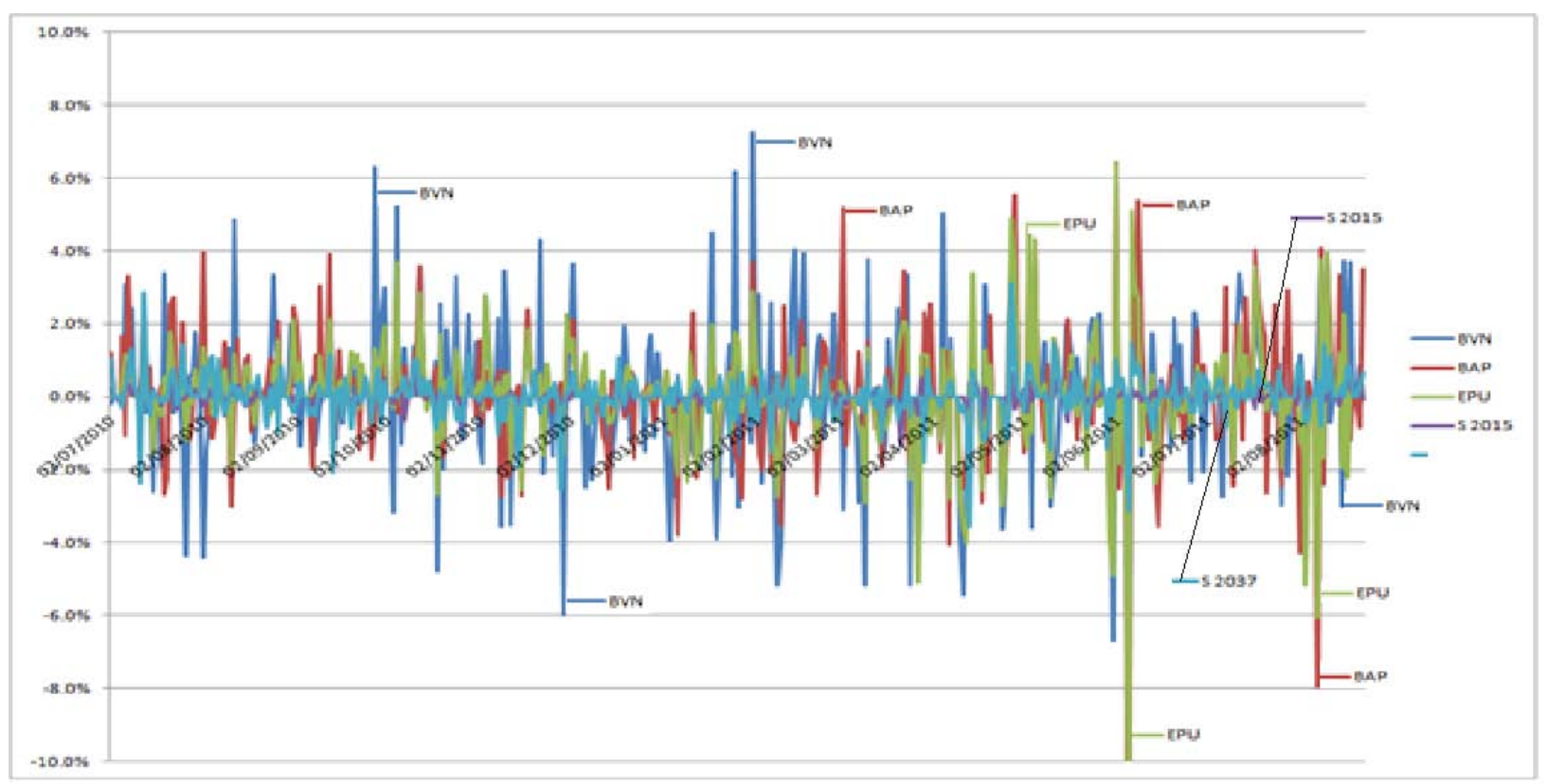

Figure 9. VAR evolution of the instruments selected.

Although the conclusions that may be drawn from this graph are limited, the authors can still hold BVN and EPU showed the widest daily price fluctuations.

The authors analyze below the variances and co-variances (see Table 1) of the financial instruments under review.

Table 1

Variance and Co Variance Matrix of the Instruments Selected

\begin{tabular}{llllll}
\hline & BVN & BAP & EPU & S 2015 & S 2037 \\
\hline BVN & $0.0410 \%$ & & & & \\
BAP & $0.0179 \%$ & $0.0328 \%$ & & & \\
EPU & $0.0218 \%$ & $0.0212 \%$ & $0.0229 \%$ & $0.0004 \%$ & $0.0037 \%$ \\
S 2015 & $0.0005 \%$ & $0.0005 \%$ & $0.0006 \%$ & $0.0006 \%$ & $0.0029 \%$ \\
S 2037 & $0.0020 \%$ & $0.0034 \%$ & & & \\
\hline
\end{tabular}

For the period under review, stocks and EPU show the greatest fluctuations and risk, when compared with fixed income assets. Only BVN and EPU recorded significant co-variance levels, since BVN appears as the asset with the greatest weight in the ETF. 


\section{Total Return and Risk Stimulation}

The following chart shows the total return from capital gains for all selected financial assets for the period under review, as well as their respective standard deviations.

EXPECTED RETURN: An average is used i.e., the arithmetic summation of data divided by the number of data extracted from a historical database.

$$
E(r)=\sum_{\frac{i=1}{n}}^{n} r_{i}
$$

where:

$n$ : number of data;

$r_{i}$ : retures of rates in period $n$.

VARIANCE: The difference between a value from the database and the expected or average value for that same set of data.

$$
\frac{\sigma^{2}=\sum_{i=1}^{n}\left(r_{i}-E_{(r)}\right)^{2}}{n}
$$

STANDARD DEviation: SD is the square root of the variance and is regarded as the basic risk measurement because it assesses both positive and negative deviations similarly. We assume a normal distribution on yields (percentages).

$$
\sigma=\sqrt{\sigma^{2}}
$$

COVARIANCE: A statistical value measuring the relationship between two random variables, or how the yields of two financial instruments or assets $c$ and $d$, "move together". A positive value reveals both moves in the same direction, while a negative value reflects movements in opposite directions. A value close to zero reveals little or no relationship at all.

$$
\operatorname{COV}_{A, B}=\underline{\sum_{i=1}^{n}\left(r_{A}-E_{\left(r_{A}\right)}\right) \cdot\left(r_{B}-E_{\left(r_{B}\right)}\right)}
$$

$n$

CoRRELATION: This statistical measure reflects the degree to which two variables are related on a linear basis. The correlation coefficient measures the association between two variables, and the positive or negative direction is shown. A correlation coefficient has values between -1 and 1 .

$$
-1<\rho_{A, B}<1 \quad \rho_{A, B}=\frac{\operatorname{cov}_{A, B}}{\sigma_{A} \cdot \sigma_{B}}
$$

After reviewing the main statistical tools, we present below the values of these statistics for the time period under review (see Table 2).

Table 2

Variance and Average Matrix of the Instruments Selected

\begin{tabular}{llllll}
\hline & BVN & BAP & EPU & S 2015 & S 2037 \\
\hline Var & $0.041 \%$ & $0.033 \%$ & $0.023 \%$ & $0.000 \%$ & $0.004 \%$ \\
Average & $0.065 \%$ & $0.023 \%$ & $0.054 \%$ & $-0.006 \%$ & $0.022 \%$ \\
\hline
\end{tabular}


As may be drawn from the above, capital gain returns are not high. In fact, carry trade resulted in larger yields from fixed income instruments during the period under examination. Assuming investors bought both types of bonds, the total return from the 2015 sovereign bond reached $-0.006 \%+9.91 \%$ in annual terms. Likewise, the 2037 sovereign bond yielded $0.022 \%+6.90 \%$. With these total returns including capital gains and carry trade gains we can create alternative optimum portfolios.

We may start with the following expected corrected returns:

$$
\text { BVN 0.065\%; BAP 0.023\%; EPU 0.054\%; S2015 9.90\%; S2037 6.922\% }
$$

To estimate the behavior of the chosen fixed income and equity instrument allocation, the authors assume that from a 1\% fixed income allocation, 50\% would be invested in the 2015 sovereign bonds, and the remaining $50 \%$ in the 2037 bond. Alternatively, a 1\% equity allocation would be distributed among BVN, BAP, and EPU in equal 33\% shares. Based on this assumption, the following graph shows the likely scenarios:

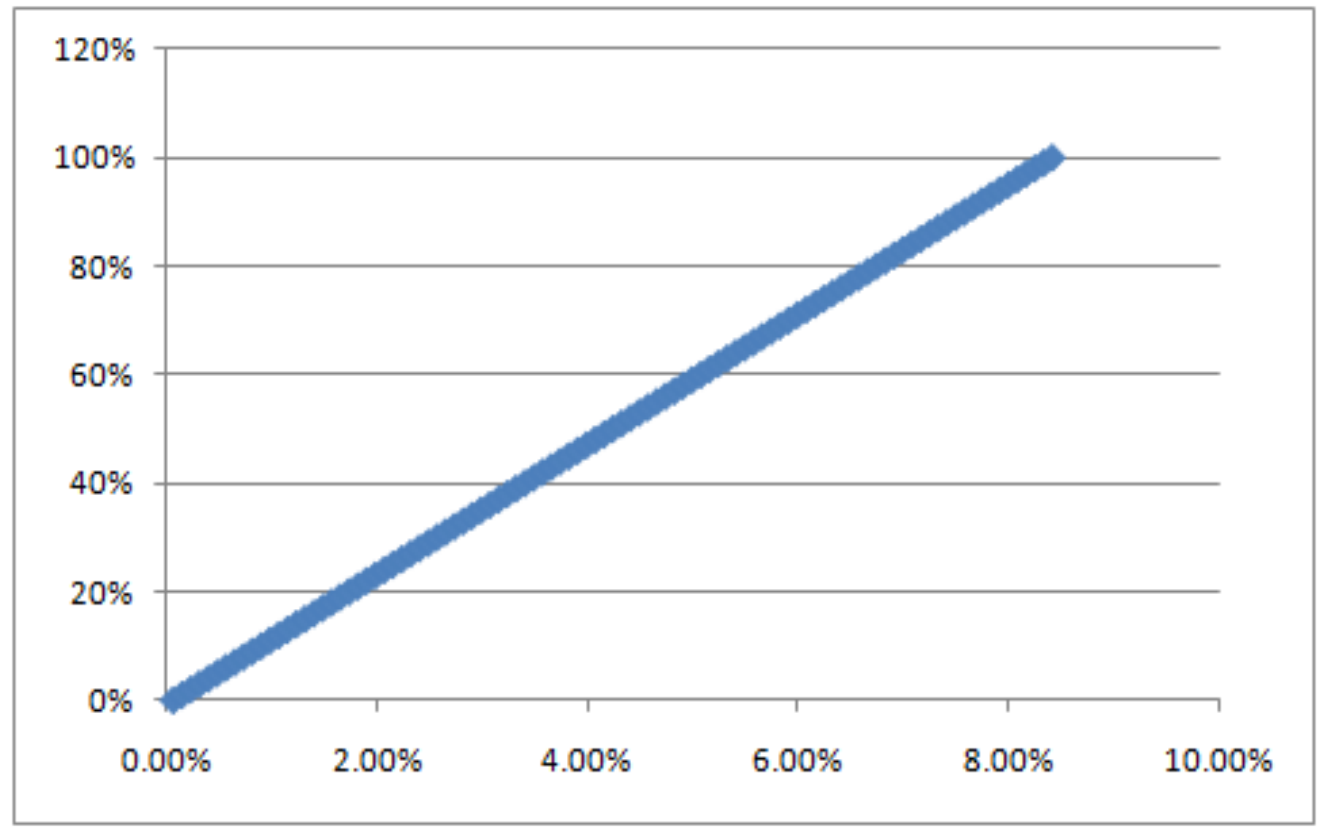

Figure 10. Capital market line.

This graph (see Figure 10) shows the greatest risk is found in stock and ETF volatility which is not compensated by the instrument's yield. The reason is that an overall decline in short term yields from equity assets. Each additional percent point in return rate free contributes significantly to the total portfolio's yield. The assumption of the portfolio efficiency curve does not hold for Peru.

The following graph showed (Figure 11) the information of the prices per instrument:

Gaby and Rosa have a hypothesis and it is that a stock's short term performance does not result in the possibility of creating optimum investment portfolios. Because of poor and even negative yields, it is better to hold a fixed income portfolio, rather than accept equity portfolio volatility and low expected yields. Consequently, the approach of possible yield scenarios does not hold for markets showing persistent stock volatility. Otherwise, when the expectation of a trend to stock price revaluation disappears in a low growth scenario, it is always preferable to hold a portfolio of fixed income instruments, even if globally stock indexes have historically yielded higher returns in the long term. 


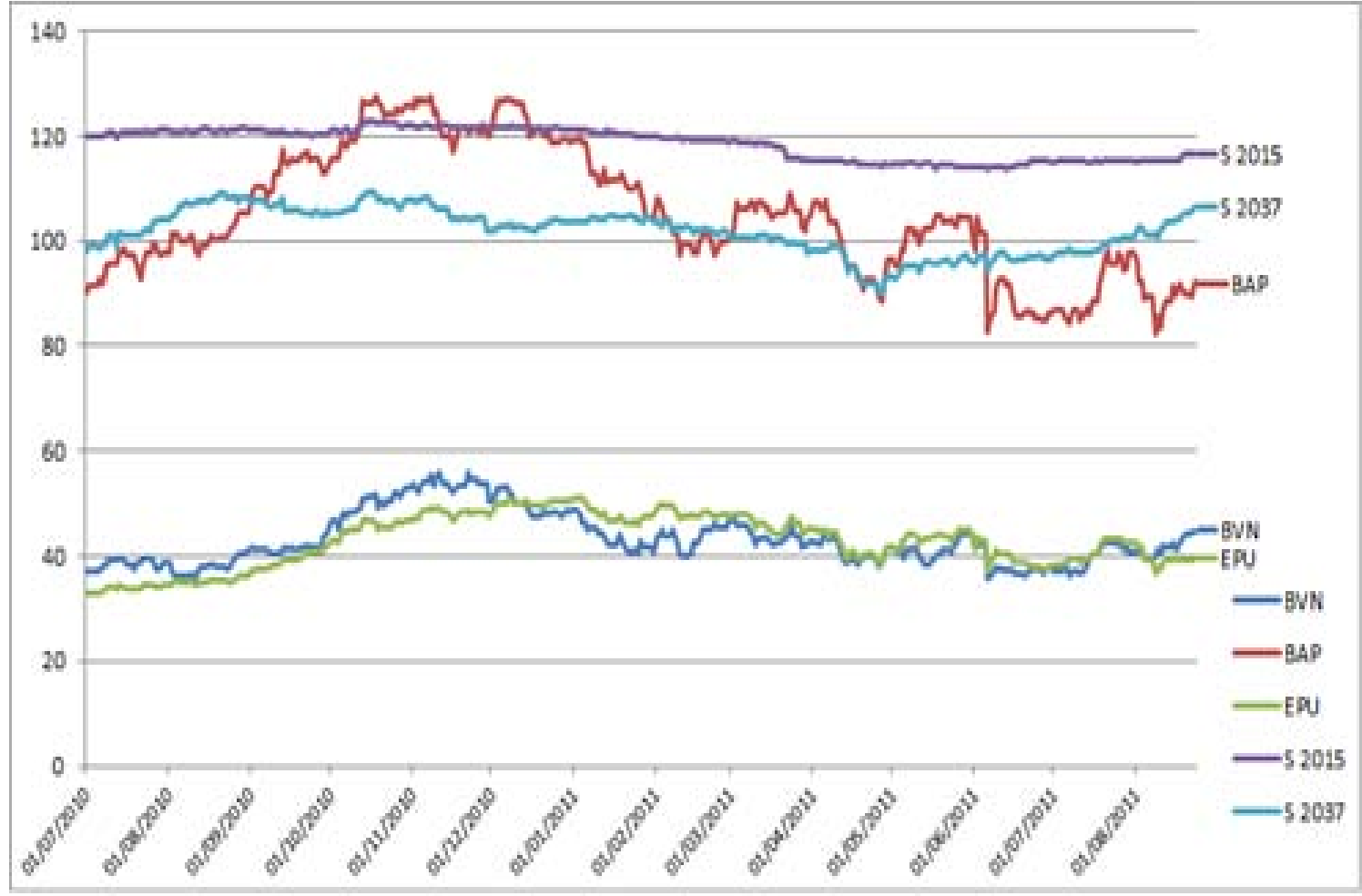

Figure 11. Prices per instrument.

\section{Conclusion}

(1) Based on the portfolio analyzed, diversifying the portfolio reduces the standard deviation (risk measure) and invest in ETF is a positive alternative because its equity combination is more valuable and has less volatility if we compare it with a simple equity.

(2) The Stock exchange integration among Chile, Colombia, and Peru will be a very powerful tool in order to diversity portfolios and if this effort includes more countries such as Mexico, the net contribution to the investor will be positive because it could increase the turn over and liquidity of the markets. Besides, the exchange rate should be analyzed in order to guarantee the settlement of the transactions.

(3) Identifying the most important risks became a significant process that all the investors have to follow, because it allows them to consider the impact of the rate and price (market risk), bid and ask tendency (liquidity risk), settlement and internal process (operational risk), credit rating and credit line with counterparts (credit risk), and one of the most important risks, reputational risk.

(4) The information becomes one of the most significant assets when an investor decides to invest, because the information reduces several risks and it is used to calculate or try to calculate some tendencies using GARCH or order methods. But it is important to indicate that predicting a market is so difficult that it is better to have a clear investment policy in order to reduce negative impact (using stop loss aspects for instance) and obtain gains with positive tendencies (selling and reinvesting with the portfolio have positive return).

\section{Drafting the Report}

Gabriela and Rosa spent some time thinking about the portfolio, the instruments that they had analyzed did 
not provided a significant return, so they are interested in evaluating other alternatives and focus on short term instruments instead of long term instruments. They consider that the return in Latam currencies (an important factor to consider in the MILA process in order to assure the settlement and, because usually the exchange rate, it is part of the monetary policy and each country has different "currency regulation" so, including the exchange rate will be a path to develop in the future, considering the local standards for MILA) and interest rate could be higher than the return investing in G-7 countries (currencies or interest rates), according to the studies done by several economists in past three years and it could generate "carry trade". In fact, Gabriela and Rosa thought that there were assets that their portfolio should have in order to mitigate the market risks.

(1) Present the major risks that they have to consider evaluating each new instrument showed in the Appendixes A1, A2, and A3.

(2) Identify Gabriela and Rosa's key priorities (short- and/or long term) and discuss the strategy to attain them.

(3) Determine the returns and standard deviation of each asset showed in Appendixes A1, A2, and A4. What do you recommend and why?

Gabriela and Rosa feel confident that the new portfolio could open a new opportunities in the New York labor market to them, so they are going to prepare several alternatives to show in the next corporate meeting.

\section{References}

Black, F. (1972). Capital market equilibrium with restricted borrowing. Journal of Business (pp. 444-455).

Chen, L., Lesmond, D. A., \& Wei, J. (2007). Corporate yield spreads and bond liquidity. Journal of Finance, 62(1), 119-149.

Días-Martínez, Z., Sánchez-Arellano, A., \& Segovia-Vargas, M. J. (2011). Prediction of financial crises by means of rough sets and decision trees. Innovar, 21(39), 83-100.

Fama, E., \& French, K. (1992, June). The cross-section of expected stock returns. Journal of Finance, 47(2), 427-65.

Fernández-Llera, R. (2011). Descentralización, deuda pública y disciplina de mercado en España. Innovar, 21(39), 67-81.

Grinblatt, M., \& Keloharju, M. (2000). The investment behavior and performance of various investor types: A study of Finland's unique data set. Journal of Financial Economics, 55, 43-67.

Hall, B. (1993). The stock market's valuation of R\&D investment during the 1980s. American Economic Review, 83(2), $259-64$.

Harris, L. (2003). Trading and exchanges: Market microstructure for practitioners. New York: Oxford University Press.

Howe, J. S. (1986). Evidence stock market over reaction. Financial Analyst Journal, 42, 74-77.

Karolyi, G. A., \& Rene, M. S. (2003). Are assets priced locally or globally? In G. Constantinides, M. Harris, \& M. Rene (Eds.), Handbook of the Economics of Finance. Stulz: North Holland.

Kopits, G. (2001, October). Fiscal rules: Useful policy framework or unnecessary ornament? IMF Working Paper No. 01/145. Kopits, G., Jiménez, J., \& Manoel, A. (2000). Responsabilidad fiscal a Nivel subnacional:Argentina y Brasil. mimeo, CEPAL. Lane, T. (1993, March). Market discipline. IMF Staff Papers, 40, 53-88.

Lee, Y., Petroni, K., \& Shen, M. (2006). Cherry picking, disclosure quality, and comprehensive income reporting choices: The case of property-liability insurers. Contemporary Accounting Research, 23(3), 655-692.

Markowitz, H. (1959). Portfolio selection. New York: John Wiley \& Sons.

Merton, R. C. (1973). An intertemporal capital asset pricing model. Econometrica, 41, 867-888.

Mishkin, F. S. (1996). Understanding financial crises: A developing country’s perspective. National Bureau of Economics Research Working Paper, 5600. M.A.:Cambridge.

Sharpe, S. A. (1990). Asymmetric information, bank lending and implicit contracts: A stylized model of customer relationships. Journal of Finance, 45, 1069-1087.

Sharpe, W. (1964). Capital asset prices: A theory of market equilibrium under conditions of risk. Journal of Finance, 19, $425-442$. Summers, L. H. (1986). Does the stock market rationally reflect fundamental values? Journal of Finance, 41,591-601.

Tobin, J. (1987). On the efficiency of the financial system. In P. M. Jackson (Ed.), Policies for Prosperity. Cambridge, M.A.: MIT Press.

Varotto, S. (2011). Liquidity risk, credit risk, market risk and bank capital. International Journal of Managerial Finance, 7(2), 134-152. 
Appendix A

Table A1

Information of Peruvian Market

\begin{tabular}{|c|c|c|c|c|c|c|c|}
\hline \multirow{3}{*}{ Date } & \multirow{3}{*}{ Exchange rate peru } & Overnight rate (\%) & \multicolumn{5}{|c|}{ Libor rate (\%) } \\
\hline & & Term & \multicolumn{5}{|c|}{ Term } \\
\hline & & 1 & 1 & 3 & 6 & 9 & 12 \\
\hline 1-Jul-11 & 2.7470 & 3.50 & 0.185 & 0.246 & 0.397 & 0.565 & 0.735 \\
\hline \begin{tabular}{|l|} 
4-Jul-11 \\
\end{tabular} & 2.7490 & 3.50 & 0.185 & 0.246 & 0.397 & 0.564 & 0.735 \\
\hline 5-Jul-11 & 2.7500 & 3.50 & 0.185 & 0.246 & 0.397 & 0.564 & 0.735 \\
\hline \begin{tabular}{|l|} 
6-Jul-11 \\
\end{tabular} & 2.7490 & 3.50 & 0.185 & 0.246 & 0.399 & 0.565 & 0.735 \\
\hline 7-Jul-11 & 2.7440 & 3.50 & 0.186 & 0.246 & 0.399 & 0.565 & 0.735 \\
\hline & & & & & & & \\
\hline 8-Jul-11 & 2.7440 & 3.50 & 0.186 & 0.246 & 0.399 & 0.567 & 0.736 \\
\hline 11-Jul-11 & 2.7450 & 3.50 & 0.186 & 0.246 & 0.403 & 0.567 & 0.735 \\
\hline 12-Jul-11 & 2.7420 & 3.50 & 0.187 & 0.249 & 0.410 & 0.575 & 0.741 \\
\hline 13-Jul-11 & 2.7420 & 3.50 & 0.187 & 0.249 & 0.413 & 0.577 & 0.743 \\
\hline 14-Jul-11 & 2.7410 & 3.50 & 0.186 & 0.250 & 0.416 & 0.578 & 0.743 \\
\hline & & & & & & & \\
\hline 15-Jul-11 & 2.7420 & 3.50 & 0.187 & 0.250 & 0.417 & 0.578 & 0.744 \\
\hline 18-Jul-11 & 2.7380 & 3.40 & 0.186 & 0.251 & 0.420 & 0.583 & 0.749 \\
\hline 19-Jul-11 & 2.7370 & 3.40 & 0.186 & 0.252 & 0.423 & 0.585 & 0.750 \\
\hline \begin{tabular}{|l|}
$20-J u l-11$ \\
\end{tabular} & 2.7380 & 3.40 & 0.187 & 0.253 & 0.423 & 0.585 & 0.751 \\
\hline 21-Jul-11 & 2.7360 & 3.40 & 0.187 & 0.253 & 0.424 & 0.585 & 0.752 \\
\hline 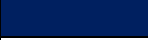 & & & & & & & \\
\hline 22-Jul-11 & 2.7370 & 3.40 & 0.187 & 0.253 & 0.423 & 0.584 & 0.752 \\
\hline 25-Jul-11 & 2.7370 & 3.40 & 0.187 & 0.252 & 0.425 & 0.584 & 0.754 \\
\hline 26-Jul-11 & 2.7370 & 3.40 & 0.187 & 0.253 & 0.425 & 0.583 & 0.755 \\
\hline 27-Jul-11 & 2.7380 & 3.45 & 0.187 & 0.253 & 0.426 & 0.585 & 0.756 \\
\hline 28-Jul-11 & Holiday & Holiday & Holiday & Holiday & Holiday & Holiday & Holiday \\
\hline & & & & & & & \\
\hline 29-Jul-11 & Holiday & Holiday & Holiday & Holiday & Holiday & Holiday & Holiday \\
\hline 1-Aug-11 & 2.7430 & 3.45 & 0.192 & 0.257 & 0.432 & 0.593 & 0.759 \\
\hline 2-Aug-11 & 2.7440 & 3.45 & 0.201 & 0.264 & 0.438 & 0.598 & 0.763 \\
\hline 3-Aug-11 & 2.7430 & 3.45 & 0.206 & 0.268 & 0.440 & 0.602 & 0.765 \\
\hline 4-Aug-11 & 2.7420 & 3.45 & 0.205 & 0.269 & 0.441 & 0.603 & 0.766 \\
\hline & & & & & & & \\
\hline 5-Aug-11 & 2.7420 & 3.45 & 0.206 & 0.272 & 0.443 & 0.604 & 0.765 \\
\hline 8-Aug-11 & 2.7530 & 3.45 & 0.206 & 0.275 & 0.443 & 0.605 & 0.767 \\
\hline 9-Aug-11 & 2.7480 & 3.45 & 0.208 & 0.278 & 0.448 & 0.608 & 0.770 \\
\hline 10-Aug-11 & 2.7520 & 3.45 & 0.207 & 0.281 & 0.448 & 0.607 & 0.767 \\
\hline 11-Aug-11 & 2.7450 & 3.45 & 0.207 & 0.286 & 0.452 & 0.609 & 0.770 \\
\hline 12-Aug-11 & 2.7410 & 3.45 & 0.208 & 0.290 & 0.457 & 0.613 & 0.773 \\
\hline 15-Aug-11 & 2.7420 & 3.45 & 0.210 & 0.292 & 0.459 & 0.617 & 0.775 \\
\hline 16-Aug-11 & 2.7410 & 3.45 & 0.210 & 0.293 & 0.460 & 0.618 & 0.776 \\
\hline 17-Aug-11 & 2.7380 & 3.45 & 0.212 & 0.296 & 0.460 & 0.618 & 0.778 \\
\hline 18-Aug-11 & 2.7390 & 3.30 & 0.213 & 0.298 & 0.463 & 0.621 & 0.780 \\
\hline 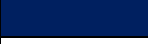 & & & & & & & \\
\hline 19-Aug-11 & 2.7350 & 3.30 & 0.215 & 0.303 & 0.467 & 0.624 & 0.784 \\
\hline 22-Aug-11 & 2.7320 & 3.30 & 0.217 & 0.308 & 0.471 & 0.628 & 0.788 \\
\hline 23-Aug-11 & 2.7320 & 3.30 & 0.218 & 0.312 & 0.475 & 0.633 & 0.792 \\
\hline 24-Aug-11 & 2.7320 & 3.30 & 0.219 & 0.314 & 0.476 & 0.635 & 0.795 \\
\hline 25-Aug-11 & 2.7320 & 3.30 & 0.221 & 0.319 & 0.480 & 0.638 & 0.798 \\
\hline
\end{tabular}


(Table A1 continued)

\begin{tabular}{|c|c|c|c|c|c|c|c|}
\hline \multirow{3}{*}{ Date } & \multirow{3}{*}{ Exchange rate peru } & \multirow{3}{*}{\begin{tabular}{|l|} 
Overnight rate (\%) \\
Term \\
1 \\
\end{tabular}} & \multicolumn{5}{|c|}{ Libor rate (\%) } \\
\hline & & & \multicolumn{5}{|c|}{ Term } \\
\hline & & & 1 & 3 & 6 & 9 & 12 \\
\hline & & & & & & & \\
\hline 26-Aug-11 & 2.7310 & 3.30 & 0.221 & 0.323 & 0.480 & 0.636 & 0.796 \\
\hline 29-Aug-11 & Holiday & Holiday & Holiday & Holiday & Holiday & Holiday & Holiday \\
\hline 30-Aug-11 & Holiday & Holiday & Holiday & Holiday & Holiday & Holiday & Holiday \\
\hline 31-Aug-11 & 2.7260 & 3.30 & 0.222 & 0.327 & 0.486 & 0.640 & 0.800 \\
\hline 1-Sep-11 & 2.7270 & 3.30 & 0.222 & 0.329 & 0.489 & 0.643 & 0.802 \\
\hline & & & & & & & \\
\hline 2-Sep-11 & 2.7300 & 3.30 & 0.222 & 0.331 & 0.490 & 0.644 & 0.803 \\
\hline 5-Sep-11 & 2.7310 & 3.30 & 0.224 & 0.333 & 0.496 & 0.648 & 0.807 \\
\hline 6-Sep-11 & 2.7300 & 3.30 & 0.226 & 0.336 & 0.502 & 0.653 & 0.814 \\
\hline 7-Sep-11 & 2.7260 & 3.25 & 0.226 & 0.337 & 0.503 & 0.656 & 0.815 \\
\hline 8-Sep-11 & 2.7250 & 3.25 & 0.225 & 0.337 & 0.504 & 0.658 & 0.818 \\
\hline & & & & & & & \\
\hline 9-Sep-11 & 2.7270 & 3.45 & 0.226 & 0.338 & 0.504 & 0.651 & 0.821 \\
\hline 12-Sep-11 & 2.7280 & 3.25 & 0.229 & 0.343 & 0.513 & 0.667 & 0.828 \\
\hline 13-Sep-11 & 2.7350 & 3.25 & 0.229 & 0.347 & 0.517 & 0.670 & 0.831 \\
\hline 14-Sep-11 & 2.7310 & 3.25 & 0.229 & 0.349 & 0.521 & 0.673 & 0.834 \\
\hline 15-Sep-11 & 2.7310 & 3.25 & 0.230 & 0.350 & 0.522 & 0.674 & 0.836 \\
\hline & & & & & & & \\
\hline 16-Sep-11 & 2.7320 & 3.45 & 0.231 & 0.351 & 0.523 & 0.673 & 0.835 \\
\hline 19-Sep-11 & 2.7380 & 3.45 & 0.231 & 0.353 & 0.525 & 0.675 & 0.836 \\
\hline 20-Sep-11 & 2.7410 & 3.40 & 0.232 & 0.355 & 0.527 & 0.676 & 0.837 \\
\hline 21-Sep-11 & 2.7480 & 3.40 & 0.234 & 0.356 & 0.529 & 0.678 & 0.839 \\
\hline 22-Sep-11 & 2.7770 & 3.40 & 0.235 & 0.358 & 0.537 & 0.685 & 0.845 \\
\hline
\end{tabular}

Note. Source: SBS, BCRP, Scotiabank, Bloomber, Reuters.

Table A2

Information of MILA and Latin America Countries

\begin{tabular}{|c|c|c|c|c|c|}
\hline \multirow{2}{*}{ DATE } & \multicolumn{5}{|c|}{ CLOSE PRICE } \\
\hline & Colombia & Chile & Brasil & México & Perú \\
\hline 1-Jul-11 & 1762.500 & 465.2500 & 1.5599 & 11.7230 & 2.750 \\
\hline 4-Jul-11 & Holiday & 465.5000 & 1.5580 & 11.6368 & 2.750 \\
\hline 5-Jul-11 & 1770.000 & 464.5000 & 1.5637 & 11.5925 & 2.746 \\
\hline 6-Jul-11 & 1766.000 & 463.7500 & 1.5662 & 11.6194 & 2.744 \\
\hline 7-Jul-11 & 1760.900 & 460.9000 & 1.5581 & 11.6544 & 2.743 \\
\hline & & & & & \\
\hline 8-Jul-11 & 1760.450 & 462.8500 & 1.5634 & 11.5738 & 2.743 \\
\hline 11-Jul-11 & 1770.000 & 467.0000 & 1.5796 & 11.6337 & 2.742 \\
\hline 12-Jul-11 & 1766.200 & 466.8500 & 1.5773 & 11.7274 & 2.742 \\
\hline 13-Jul-11 & 1757.300 & 462.6500 & 1.5762 & 11.7867 & 2.742 \\
\hline 14-Jul-11 & 1747.650 & 462.1500 & 1.5729 & 11.7170 & 2.740 \\
\hline & & & & & \\
\hline 15-Jul-11 & 1759.850 & 462.4000 & 1.5743 & 11.7010 & 2.738 \\
\hline 18-Jul-11 & 1757.500 & 463.3500 & 1.5828 & 11.7178 & 2.738 \\
\hline 19-Jul-11 & 1757.250 & 461.9000 & 1.5691 & 11.7877 & 2.736 \\
\hline 20-Jul-11 & Holiday & 463.0000 & 1.5651 & 11.6964 & 2.737 \\
\hline 21-Jul-11 & 1754.000 & 460.9000 & 1.5567 & 11.6638 & 2.736 \\
\hline
\end{tabular}


(Table A2 continued)

\begin{tabular}{|c|c|c|c|c|c|}
\hline \multirow{2}{*}{ DATE } & \multicolumn{5}{|c|}{ CLOSE PRICE } \\
\hline & Colombia & Chile & Brasil & México & Perú \\
\hline 22-Jul-11 & 1755.800 & 461.4700 & 1.5547 & 11.6174 & 2.736 \\
\hline 25-Jul-11 & 1763.500 & 462.7000 & 1.5449 & 11.6393 & 2.741 \\
\hline 26-Jul-11 & 1758.700 & 457.5000 & 1.5345 & 11.6641 & 2.736 \\
\hline 27-Jul-11 & 1767.500 & 456.8000 & 1.5639 & 11.6172 & 2.741 \\
\hline 28-Jul-11 & 1773.000 & 455.7600 & 1.5651 & 11.6527 & Holiday \\
\hline 29-Jul-11 & 1770000 & $4\ulcorner 07000$ & $15 \Gamma C ?$ & 111 & IS lido \\
\hline \begin{tabular}{|l|}
$1-$ Aug-11 \\
\end{tabular} & \begin{tabular}{|l|l|l|l|}
1767100 \\
\end{tabular} & \begin{tabular}{|l}
457000000 \\
\end{tabular} & $\frac{1.0005}{15551}$ & \begin{tabular}{|l|l}
1.0021 \\
117125
\end{tabular} & this \\
\hline 2 -Aug-11 & \begin{tabular}{|l|}
1771.150 \\
\end{tabular} & 458.9000 & 1.5656 & 11.7514 & 2.742 \\
\hline 3-Aug-11 & 1771.250 & 458.5000 & 1.5651 & 11.7657 & 2.742 \\
\hline 4-Aug-11 & 1786.000 & 462.1500 & 1.5752 & 11.8473 & 2.742 \\
\hline & & & & & \\
\hline 5-Aug-11 & 1789.300 & 465.2000 & 1.5895 & 11.9523 & 2.743 \\
\hline 8-Aug-11 & 1815.500 & 472.6000 & 1.5999 & 11.9794 & 2.754 \\
\hline 9-Aug-11 & 1812.500 & 473.0000 & 1.6334 & 12.1845 & 2.749 \\
\hline 10-Aug-11 & 1796.000 & 473.3000 & 1.6183 & 12.3710 & 2.750 \\
\hline 11-Aug-11 & \begin{tabular}{|l|}
1788.800 \\
\end{tabular} & 471.1000 & 1.6306 & 12.3221 & 2.745 \\
\hline 12_Aня-11 & 1785050 & 4705000 & 16157 & 113899 & 2743 \\
\hline \begin{tabular}{|l|}
$15-A u g-11$ \\
\end{tabular} & \begin{tabular}{|l} 
Holiday \\
\end{tabular} & Holiday & 1.5956 & 12.2992 & 2.740 \\
\hline 16-Aug-11 & 1775.100 & 472.0000 & 1.5918 & 12.2424 & 2.741 \\
\hline 17-Aug-11 & 1766.350 & 466.4500 & 1.5830 & 12.2631 & 2.736 \\
\hline 18-Aug-11 & 1777.500 & 470.5000 & 1.6062 & 12.1651 & 2.738 \\
\hline 19-Aug-11 & 1783.000 & 468.6000 & 1.5960 & 12.3685 & 2.733 \\
\hline 22-Aug-11 & 1780.000 & 468.4000 & 1.6009 & 12.2386 & 2.733 \\
\hline 23-Aug-11 & 1789.000 & 467.2500 & 1.6036 & 12.2948 & 2.732 \\
\hline 24-Aug-11 & 1786.010 & 467.0000 & 1.6039 & 12.3357 & 2.733 \\
\hline 25-Aug-11 & 1790.900 & 466.9500 & 1.6154 & 12.3952 & 2.731 \\
\hline & & & & & \\
\hline 26-Aug-11 & 1794.350 & 465.8500 & 1.6114 & 12.4259 & 2.730 \\
\hline 29-Aug-11 & 1790.300 & 464.9000 & 1.5974 & 12.4953 & Holiday \\
\hline 30-Aug-11 & 1789.000 & 465.0500 & 1.5904 & 12.4148 & Holiday \\
\hline 31-Aug-11 & 1782.500 & 461.0500 & 1.5872 & 12.4838 & 2.727 \\
\hline 1-Sep-11 & 1779.500 & 459.6100 & 1.6040 & 12.3480 & 2.729 \\
\hline 2 Con 11 & חم0 רח & (150000000 & 190210 & תבת ת12 & מרד ר \\
\hline 2-Sep-11 & 1783.000 & 459.8000 & 1.6343 & 12.2616 & 2.729 \\
\hline 5-Sep-11 & 1782.800 & 462.8000 & 1.6522 & 12.3735 & 2.735 \\
\hline 6-Sep-11 & 1791.200 & 464.2500 & 1.6583 & 12.5353 & 2.727 \\
\hline 7-Sep-11 & 1790.000 & 462.8000 & Holiday & 12.5102 & 2.725 \\
\hline 8-Sep-11 & 1788.500 & 462.6600 & 1.6566 & 12.4661 & 2.724 \\
\hline & & & & & \\
\hline 9-Sep-11 & 1798.000 & 469.4000 & 1.6774 & 12.4956 & 2.728 \\
\hline 12-Sep-11 & 1821.000 & 476.0000 & 1.6899 & 12.6324 & 2.734 \\
\hline 13-Sep-11 & 1813.480 & 475.1000 & 1.7127 & 12.7687 & 2.730 \\
\hline 14-Sep-11 & 1826.500 & 478.8000 & 1.7288 & 12.8994 & 2.732 \\
\hline 15-Sep-11 & 1820.100 & 478.1500 & 1.7106 & 12.9646 & 2.729 \\
\hline
\end{tabular}


(Table A2 continued)

\begin{tabular}{|l|l|l|l|l|l|}
\hline DATE & CLOSE PRICE & Brasil & México & Perú \\
\hline & Colombia & Chile & & & \\
\hline & & & & & \\
\hline $16-S e p-11$ & 1821.450 & 480.5000 & 1.7122 & Holiday & 2.734 \\
\hline $19-S e p-11$ & 1857.000 & Holiday & 1.7763 & 12.9127 & 2.740 \\
\hline $20-$ Sep-11 & 1860.500 & 489.8000 & 1.7870 & 13.1860 & 2.735 \\
\hline $21-$ Sep-11 & 1874.000 & 499.9000 & 1.8280 & 13.1669 & 2.758 \\
\hline $22-$ Sep-11 & 1915.000 & 523.1000 & 1.9016 & 13.4045 & 2.771 \\
\hline
\end{tabular}

Note. Source: BVC, BEC, BCB, DOF.

Table A3

G 7 Currencies Open Prices

\begin{tabular}{|c|c|c|c|c|c|c|c|c|}
\hline \multirow{3}{*}{ DATE } & \multicolumn{8}{|c|}{ G7 CURRENCY } \\
\hline & \multicolumn{8}{|c|}{\begin{tabular}{|l|} 
OPEN PRICE \\
\end{tabular}} \\
\hline & EUR/USD & EUR/GBP & EUR/JPY & EUR/CAD & GBP/USD & USD/CAD & USD/JPY & GBP/JPY \\
\hline 1-Jul-11 & $1.4509 / 1.4510$ & $0.9034 / 0.9035$ & $117.38 / 117.40$ & $1.3962 / 1.3964$ & $1.6061 / 1.6062$ & $0.9604 / 0.9605$ & $80.90 / 80.91$ & $129.92 / 129.95$ \\
\hline 4-Jul-11 & $1.4510 / 1.4510$ & $0.9031 / 0.9032$ & \begin{tabular}{|l|}
$117.30 / 117.32$ \\
\end{tabular} & $1.3917 / 1.3919$ & $1.6065 / 1.6067$ & $0.9611 / 0.9613$ & $80.84 / 80.85$ & $129.88 / 129.90$ \\
\hline 5-Jul-11 & $1.4476 / 1.4476$ & $0.8985 / 0.8987$ & 117.33/117.35 & $1.3929 / 1.3932$ & $1.6109 / 1.6110$ & $0.9621 / 0.9622$ & $81.05 / 81.06$ & $130.57 / 130.59$ \\
\hline 6-Jul-11 & $1.4333 / 1.4333$ & $0.8945 / 0.8946$ & $115.92 / 115.93$ & $1.3830 / 1.3833$ & $1.6021 / 1.6022$ & $0.9658 / 0.9660$ & $80.87 / 80.88$ & $129.58 / 129.60$ \\
\hline 7-Jul-11 & $1.4337 / 1.4338$ & $0.8971 / 0.8972$ & 116.48/116.49 & $1.3738 / 1.3738$ & $1.5980 / 1.5982$ & $0.9583 / 0.9584$ & $81.24 / 81.25$ & $129.83 / 129.85$ \\
\hline 8-Jul-11 & $1.4318 / 1.4319$ & $0.8931 / 0.8932$ & $115.44 / 115.46$ & $1.3645 / 1.3645$ & $1.6031 / 1.6032$ & $0.9627 / 0.9629$ & $80.63 / 80.64$ & $129.25 / 129.27$ \\
\hline 11-Jul-11 & $1.4073 / 1.4076$ & $0.8832 / 0.8835$ & $113.13 / 113.16$ & $1.3625 / 1.3627$ & $1.5933 / 1.5933$ & $0.9659 / 0.9662$ & $80.39 / 80.42$ & $128.05 / 128.11$ \\
\hline 12-Jul-11 & $1.3977 / 1.3980$ & $0.8811 / 0.8813$ & $111.33 / 111.33$ & $1.3584 / 1.3584$ & $1.5863 / 1.5866$ & $0.9681 / 0.9684$ & $79.62 / 79.65$ & $126.33 / 126.36$ \\
\hline 13-Jul-11 & $1.4137 / 1.4139$ & $0.8783 / 0.8785$ & $117.65 / 117.68$ & $1.3520 / 1.3522$ & $1.6102 / 1.6105$ & $0.9592 / 0.9592$ & 78.81/78.85 & $127.19 / 127.21$ \\
\hline 14-Jul-11 & $1.4244 / 1.4247$ & $0.8818 / 0.8821$ & $112.63 / 112.66$ & $1.3597 / 1.3600$ & $1.6151 / 1.6154$ & $0.9571 / 0.9573$ & 79.06/79.09 & $127.69 / 127.75$ \\
\hline & & & & & & & & \\
\hline 15-Jul-11 & $1.4130 / 1.4150$ & 0.8731/0.8751 & 111.89/112.01 & $1.3538 / 1.3540$ & $1.608 / 1.614$ & $0.9651 / 0.9655$ & 78.15/78.17 & $125.18 / 125.22$ \\
\hline 18-Jul-11 & $1.4029 / 1.4050$ & $0.8730 / 0.8740$ & $110.66 / 111.67$ & $1.3461 / 1.3465$ & $1.6015 / 1.6020$ & $0.9543 / 0.9550$ & 77.25/77.32 & $120.35 / 120.38$ \\
\hline 19-Jul-11 & $1.4164 / 1.4167$ & $0.8772 / 0.8775$ & $111.81 / 111.83$ & $1.3532 / 1.3534$ & $1.6145 / 1.6148$ & $0.9505 / 0.9508$ & 78.91/78.94 & $127.43 / 127.46$ \\
\hline 20-Jul-11 & $1.4181 / 1.4184$ & $0.8799 / 0.8802$ & $111.89 / 111.92$ & $1.3449 / 1.3451$ & $1.6114 / 1.6117$ & $0.9484 / 0.9487$ & 78.89/78.92 & $127.12 / 127.18$ \\
\hline 21-Jul-11 & $1.4323 / 1.4326$ & $0.8812 / 0.8815$ & $112.57 / 112.60$ & $1.3445 / 1.3447$ & $1.6252 / 1.6255$ & $0.9451 / 0.9454$ & 78.58/78.61 & $127.71 / 127.77$ \\
\hline 22-Jul-11 & $1.4333 / 1.4336$ & $0.8807 / 0.8810$ & $112.45 / 112.48$ & $1.3655 / 1.3658$ & $1.6272 / 1.6275$ & $0.9512 / 0.9515$ & 78.44/78.47 & $127.64 / 127.70$ \\
\hline 25-Jul-11 & $1.4351 / 1.4354$ & $0.8811 / 0.8814$ & $112.17 / 112.20$ & $1.3597 / 1.3599$ & $1.6285 / 1.6288$ & $0.9462 / 0.9465$ & 78.15/78.18 & $127.26 / 127.32$ \\
\hline 26-Jul-11 & $1.4461 / 1.4464$ & $0.8823 / 0.8826$ & $112.86 / 112.89$ & $1.3619 / 1.3623$ & $1.6388 / 1.6391$ & $0.9433 / 0.9436$ & 78.03/78.06 & 127.88/128.94 \\
\hline 27-Jul-11 & $1.4431 / 1.4434$ & $0.8813 / 0.8816$ & $112.33 / 112.36$ & $1.3621 / 1.3625$ & $1.6372 / 1.6375$ & $0.9427 / 0.9431$ & $77.83 / 77.86$ & $127.42 / 127.48$ \\
\hline 28-Jul-11 & Holiday & Holiday & Holiday & Holiday & Holiday & Holiday & Holiday & Holiday \\
\hline & & & & & & & & \\
\hline 29-Jul-11 & Holiday & Holiday & Holiday & Holiday & Holiday & Holiday & Holiday & Holiday \\
\hline 1-Aug-11 & $1.4235 / 1.4238$ & $0.8732 / 0.8738$ & 109.87/109.90 & $1.3706 / 1.3709$ & $1.6278 / 1.6280$ & $0.9560 / 0.9563$ & $77.17 / 77.19$ & $125.65 / 125.69$ \\
\hline 2-Aug-11 & $1.4241 / 1.4244$ & $0.8753 / 0.8756$ & 109.99/110.02 & $1.3618 / 1.3620$ & $1.6267 / 1.6271$ & $0.9575 / 0.9578$ & $77.22 / 77.25$ & $125.61 / 125.67$ \\
\hline 3-Aug-11 & $1.4299 / 1.4302$ & $0.8728 / 0.8731$ & $110.02 / 110.05$ & $1.3720 / 1.3724$ & $1.6381 / 1.6384$ & $0.9602 / 0.9605$ & 76.98/76.96 & $126.01 / 126.07$ \\
\hline 4-Aug-11 & $1.4169 / 1.4172$ & $0.8671 / 0.8674$ & $112.11 / 112.14$ & $1.3825 / 1.3829$ & $1.6339 / 1.6342$ & $0.9702 / 0.9705$ & 79.11/79.14 & 129.26/129.32 \\
\hline 5-Aug-11 & $1.4193 / 1.4196$ & $0.8681 / 0.8683$ & $111.36 / 111.39$ & 1.3891/1.3899 & $1.6349 / 1.6352$ & 0.9802/0.9805 & 78.45/78.48 & $128.25 / 128.31$ \\
\hline 8-Aug-11 & $1.4230 / 1.4233$ & 0.8699/0.8702 & $110.31 / 110.33$ & $1.4025 / 1.4029$ & $1.6355 / 1.6358$ & $0.9888 / 0.9891$ & 77.51/77.54 & $126.76 / 126.82$ \\
\hline 9-Aug-11 & $1.4250 / 1.4253$ & $0.8728 / 0.8731$ & $110.11 / 110.14$ & $1.4139 / 1.4143$ & $1.6323 / 1.6326$ & $0.9935 / 0.9938$ & $77.26 / 77.29$ & $126.11 / 126.17$ \\
\hline 10-Aug-11 & $1.4229 / 1.4232$ & $0.8796 / 0.8799$ & 108.76/108.79 & $1.4131 / 1.4133$ & $1.6174 / 1.6177$ & $0.9876 / 0.9879$ & $76.42 / 76.45$ & $123.62 / 123.66$ \\
\hline 11-Aug-11 & $1.4219 / 1.4222$ & $0.8773 / 0.8776$ & $109.12 / 109.15$ & $1.4087 / 1.4091$ & $1.6205 / 1.6208$ & $0.9930 / 0.9933$ & 76.73/76.76 & $124.34 / 124.40$ \\
\hline
\end{tabular}


(Table A3 continued)

\begin{tabular}{|c|c|c|c|c|c|c|c|c|}
\hline \multirow{3}{*}{ DATE } & \multicolumn{8}{|c|}{ G7 CURRENCY } \\
\hline & \multicolumn{8}{|l|}{ OPEN PRICE } \\
\hline & EUR/USD & EUR/GBP & EUR/JPY & EUR/CAD & GBP/USD & USD/CAD & USD/JPY & GBP/JPY \\
\hline & & & & & & & & \\
\hline 12-Aug-11 & $1.4271 / 1.4274$ & $0.8759 / 0.8762$ & $109.39 / 109.41$ & $1.4059 / 1.4063$ & $1.6290 / 1.6293$ & $0.9856 / 0.9859$ & 76.64/76.67 & $124.85 / 124.91$ \\
\hline 15-Aug-11 & $1.4404 / 1.4407$ & $0.8807 / 0.8810$ & $110.40 / 110.43$ & $1.4110 / 1.4112$ & $1.6354 / 1.6357$ & $0.9853 / 0.9856$ & 76.63/76.66 & $125.32 / 125.38$ \\
\hline 16-Aug-11 & $1.4391 / 1.4394$ & $0.8779 / 0.8782$ & $110.60 / 110.63$ & $1.4162 / 1.4165$ & $1.6388 / 1.6391$ & 0.9828/0.9831 & 76.85/76.88 & $125.94 / 126.00$ \\
\hline 17-Aug-11 & $1.4486 / 1.4489$ & $0.8781 / 0.8784$ & $110.84 / 110.87$ & $1.4165 / 1.4167$ & $1.6494 / 1.6497$ & $0.9789 / 0.9792$ & $76.50 / 76.53$ & $126.18 / 126.24$ \\
\hline 18-Aug-11 & $1.4336 / 1.4339$ & $0.8687 / 0.8690$ & 109.82/109.85 & $1.4170 / 1.4175$ & $1.6502 / 1.6506$ & $0.9909 / 0.9912$ & $76.59 / 76.62$ & $126.39 / 126.45$ \\
\hline 19-Aug-11 & $1.4414 / 1.4417$ & $0.8697 / 0.8701$ & $110.14 / 110.17$ & 1.4185/1.4189 & $1.6570 / 1.6573$ & $0.9871 / 0.9874$ & 76.40/76.43 & $126.61 / 126.66$ \\
\hline 22-Aug-11 & $1.4419 / 1.4422$ & $0.8739 / 0.8742$ & $110.67 / 110.69$ & $1.4190 / 1.4194$ & $1.6498 / 1.6501$ & $0.9856 / 0.9860$ & 76.73/76.76 & $126.59 / 126.65$ \\
\hline 23-Aug-11 & $1.4390 / 1.4393$ & $0.8711 / 0.8714$ & $110.16 / 110.19$ & $1.4257 / 1.4260$ & $1.6517 / 1.6520$ & $0.9883 / 0.9886$ & $76.54 / 76.57$ & $126.42 / 126.48$ \\
\hline 24-Aug-11 & $1.4468 / 1.4471$ & $0.8794 / 0.8797$ & $110.71 / 110.74$ & $1.4262 / 1.4266$ & $1.6450 / 1.6453$ & $0.9855 / 0.9858$ & 76.51/76.54 & $125.86 / 125.92$ \\
\hline 25-Aug-11 & $1.4432 / 1.4435$ & $0.8824 / 0.8827$ & $111.24 / 111.27$ & $1.4215 / 1.4219$ & $1.6353 / 1.6356$ & $0.9807 / 0.9810$ & 77.07/77.11 & $126.04 / 126.10$ \\
\hline 26-Aug-11 & $1.4408 / 1.4411$ & $0.8861 / 0.8864$ & $110.41 / 110.44$ & 1.4239/1.4241 & $1.6259 / 1.6262$ & $0.9902 / 0.9905$ & 76.62/76.65 & $124.56 / 124.62$ \\
\hline 29-Aug-11 & $1.4536 / 1.4539$ & $0.8852 / 0.8855$ & 111.61/111.65 & $1.4154 / 1.4157$ & $1.6418 / 1.6421$ & $0.9760 / 0.9763$ & 76.77/76.80 & $126.05 / 126.11$ \\
\hline 30-Aug-11 & $1.4222 / 1.4225$ & $0.8805 / 0.8808$ & $110.12 / 110.15$ & $1.4098 / 1.4101$ & $1.6637 / 1.6642$ & $0.9540 / 0.9544$ & $74.55 / 74.60$ & $124.45 / 124.49$ \\
\hline 31-Aug-11 & $1.4438 / 1.4441$ & $0.8845 / 0.8848$ & $110.56 / 110.59$ & $1.4138 / 1.4141$ & $1.6323 / 1.6326$ & $0.9756 / 0.9759$ & 76.56/76.59 & $124.97 / 125.03$ \\
\hline 1-Sep-11 & $1.4238 / 1.4241$ & $0.8815 / 0.8818$ & 109.79/109.82 & $1.3950 / 1.3954$ & $1.6151 / 1.6154$ & $0.9757 / 0.9760$ & 77.10/77.13 & $124.52 / 124.58$ \\
\hline 2-Sep-11 & $1.4198 / 1.4201$ & $0.8772 / 0.8775$ & 109.04/109.07 & $1.3941 / 1.3944$ & $1.6182 / 1.6185$ & $0.9819 / 0.9822$ & 76.79/76.82 & $124.26 / 124.32$ \\
\hline 5-Sep-11 & $1.4105 / 1.4108$ & $0.8751 / 0.8754$ & 108.48/108.51 & $1.3964 / 1.3968$ & $1.6116 / 1.6119$ & 0.9891/0.9894 & 76.89/76.92 & $123.92 / 123.98$ \\
\hline 6-Sep-11 & $1.4041 / 1.4044$ & $0.8759 / 0.8762$ & 108.83/108.86 & 1.3989/1.3992 & $1.6028 / 1.6031$ & $0.9946 / 0.9949$ & $77.49 / 77.52$ & $124.21 / 124.27$ \\
\hline 7-Sep-11 & $1.4013 / 1.4016$ & $0.8774 / 0.8777$ & 108.39/108.42 & 1.3874/1.3877 & $1.5968 / 1.5971$ & $0.9893 / 0.9896$ & 77.34/77.37 & 123.49/123.55 \\
\hline 8-Sep-11 & $1.4003 / 1.4006$ & $0.8713 / 0.8716$ & 108.30/108.33 & |1.3821/1.3825 & $1.6068 / 1.6071$ & 0.9836/0.9839 & 77.33/77.36 & $124.25 / 124.31$ \\
\hline 9-Sep-11 & $1.3691 / 1.3694$ & $0.8620 / 0.8623$ & $106.44 / 106.47$ & $1.3715 / 1.3718$ & $1.5880 / 1.5883$ & $0.9957 / 0.9960$ & 77.74/77.77 & $123.45 / 123.51$ \\
\hline 12-Sep-11 & $1.3611 / 1.3614$ & $0.8606 / 0.8609$ & $105.10 / 105.13$ & $1.3665 / 1.3668$ & $1.5814 / 1.5817$ & $0.9960 / 0.9963$ & $77.20 / 77.23$ & $122.08 / 122.14$ \\
\hline 13-Sep-11 & 1.3686/1.3689 & $0.8648 / 0.8651$ & $105.16 / 105.19$ & $1.3541 / 1.3545$ & $1.5824 / 1.5827$ & $0.9910 / 0.9913$ & 76.82/76.85 & 121.56/121.62 \\
\hline 14-Sep-11 & $1.3695 / 1.3698$ & $0.8675 / 0.8678$ & $105.06 / 105.09$ & $1.3579 / 1.3583$ & $1.5785 / 1.5788$ & $0.9910 / 0.9913$ & $76.70 / 76.73$ & $121.07 / 121.13$ \\
\hline 15-Sep-11 & $1.3880 / 1.3883$ & $0.8759 / 0.8762$ & $106.55 / 106.58$ & $1.3630 / 1.3635$ & $1.5843 / 1.5846$ & $0.9847 / 0.9850$ & $76.75 / 76.78$ & $121.59 / 121.65$ \\
\hline 16-Sep-11 & $1.3800 / 1.3803$ & $0.8727 / 0.8730$ & 105.93/105.96 & $1.3559 / 1.3562$ & $1.5810 / 1.5813$ & $0.9834 / 0.9837$ & $76.75 / 76.78$ & $121.34 / 121.40$ \\
\hline 19-Sep-11 & $1.3613 / 1.3616$ & $0.8693 / 0.8696$ & $104.52 / 104.55$ & $1.3420 / 1.3423$ & $1.5657 / 1.5660$ & $0.9897 / 0.9900$ & 76.77/76.80 & $120.20 / 120.26$ \\
\hline 20-Sep-11 & $1.3684 / 1.3687$ & $0.8765 / 0.8768$ & $104.48 / 104.51$ & $1.3590 / 1.3594$ & $1.5610 / 1.5613$ & $0.9989 / 0.9992$ & 76.34/76.37 & $119.17 / 119.23$ \\
\hline 21-Sep-11 & $1.3684 / 1.3687$ & $0.8765 / 0.8768$ & $104.48 / 104.51$ & $1.3590 / 1.3594$ & $1.5610 / 1.5613$ & $0.9989 / 0.9992$ & 76.34/76.37 & 119.17/119.23 \\
\hline 22-Sep-11 & $1.3468 / 1.3471$ & $0.8771 / 0.8774$ & $102.73 / 102.76$ & $1.3891 / 1.3894$ & $1.5353 / 1.5356$ & $1.0292 / 1.0295$ & 76.27/76.30 & $117.11 / 117.17$ \\
\hline
\end{tabular}

Note. Source: Several platforms. 
Table A4

G 7 Currencies Close Prices

\begin{tabular}{|c|c|c|c|c|c|c|c|c|}
\hline \multirow{3}{*}{ DATE } & \multicolumn{8}{|c|}{ G7 CURRENCY } \\
\hline & \multicolumn{8}{|l|}{ CLOSE PRICE } \\
\hline & EUR/USD & EUR/GBP & EUR/JPY & EUR/CAD & GBP/USD & USD/CAD & USD/JPY & GBP/JPY \\
\hline 1-Jul-11 & $1.4512 / 1.4515$ & $0.9030 / 0.9032$ & $117.43 / 117.46$ & $1.3967 / 1.3969$ & $1.6064 / 1.6065$ & $0.9600 / 0.9602$ & $80.93 / 80.94$ & 129.97/129.99 \\
\hline 4-Jul-11 & $1.4512 / 1.4512$ & $0.9033 / 0.9034$ & 117.28/117.29 & $1.3921 / 1.3923$ & $1.6062 / 1.6064$ & $0.9615 / 0.9617$ & $80.87 / 80.89$ & 129.79/129.84 \\
\hline 5-Jul-11 & $1.4408 / 1.4409$ & $0.8976 / 0.8978$ & 116.76/116.78 & $1.3924 / 1.3927$ & $1.6049 / 1.6051$ & $0.9626 / 0.9627$ & $81.04 / 81.05$ & 130.06/130.08 \\
\hline 6-Jul-11 & $1.4304 / 1.4305$ & $0.8946 / 0.8948$ & $115.74 / 115.76$ & $1.3835 / 1.3837$ & $1.5987 / 1.5989$ & $0.9654 / 0.9656$ & $80.92 / 80.92$ & 129.36/129.39 \\
\hline 7-Jul-11 & $1.4355 / 1.4356$ & $0.8990 / 0.8991$ & $116.60 / 116.62$ & $1.3736 / 1.3736$ & $1.5967 / 1.5968$ & $0.9587 / 0.9588$ & $81.22 / 81.23$ & 129.69/129.72 \\
\hline 8-Jul-11 & $1.4244 / 1.4076$ & $0.8887 / 0.8888$ & $114.87 / 114.88$ & $1.3647 / 1.3647$ & $1.6026 / 1.6027$ & $0.9615 / 0.9616$ & $80.64 / 80.65$ & $129.23 / 129.26$ \\
\hline 11-Jul-11 & $1.4022 / 1.4023$ & $0.8811 / 0.8814$ & $112.36 / 112.39$ & $1.3615 / 1.3618$ & $1.5909 / 1.5912$ & $0.9684 / 0.9687$ & $80.13 / 80.16$ & 127.48/127.54 \\
\hline 12-Jul-11 & $1.3982 / 1.3985$ & $0.8812 / 0.8814$ & 111.29/111.31 & $1.3580 / 1.3582$ & $1.5860 / 1.5862$ & $0.9679 / 0.9680$ & 79.59/79.61 & $126.27 / 126.30$ \\
\hline 13-Jul-11 & $1.4142 / 1.4145$ & $0.8778 / 0.8781$ & $117.71 / 117.73$ & $1.3525 / 1.3527$ & 1.6108/1.6111 & $0.9594 / 0.9597$ & $78.97 / 79.00$ & $127.24 / 127.26$ \\
\hline 14-Jul-11 & $1.4141 / 1.4144$ & $0.8762 / 0.8765$ & $111.81 / 111.84$ & $1.3603 / 1.3605$ & $1.6136 / 1.6139$ & $0.9593 / 0.9596$ & 79.06/79.09 & $127.57 / 127.63$ \\
\hline
\end{tabular}

\begin{tabular}{|l|l|l|l|l|l|l|l|l|}
\hline 15-Jul-11 & $1.4170 / 1.4190$ & $0.8778 / 0.8780$ & $112.35 / 112.35$ & $1.3543 / 1.3549$ & $1.614 / 1.618$ & $0.9659 / 0.9662$ & $78.08 / 78.11$ & $125.25 / 125.32$ \\
\hline
\end{tabular} \begin{tabular}{|l|l|l|l|l|l|l|l|l|}
\hline 18-Jul-11 & $1.4139 / 1.4142$ & $0.8790 / 0.8800$ & $111.69 / 111.72$ & $1.3469 / 1.3472$ & $1.6127 / 1.6130$ & $0.9634 / 0.9637$ & $77.35 / 77.39$ & $120.44 / 120.49$ \\
\hline
\end{tabular} \begin{tabular}{|l|l|l|l|l|l|l|l|l|}
\hline 19-Jul-11 & $1.4155 / 1.4158$ & $0.8763 / 0.8765$ & $111.85 / 111.85$ & $1.3525 / 1.3528$ & $1.6151 / 1.6154$ & $0.9511 / 0.9514$ & $78.77 / 78.81$ & $127.49 / 127.53$ \\
\hline
\end{tabular} \begin{tabular}{|l|l|l|l|l|l|l|l|l|}
\hline 20-Jul-11 & $1.4171 / 1.4175$ & $0.8805 / 0.8807$ & $111.95 / 111.97$ & $1.3438 / 1.3440$ & $1.6111 / 1.6115$ & $0.9489 / 0.9491$ & $78.91 / 78.94$ & $127.20 / 127.25$ \\
\hline
\end{tabular} \begin{tabular}{|l|l|l|l|l|l|l|l|l|l|}
\hline 21-Jul-11 & $1.4328 / 1.4330$ & $0.8807 / 0.8809$ & $112.62 / 112.65$ & $1.3441 / 1.3443$ & $1.6247 / 1.6249$ & $0.9456 / 0.9458$ & $78.63 / 78.66$ & $127.80 / 127.82$ \\
\hline
\end{tabular}

\begin{tabular}{|l|c|c|c|c|c|c|c|c|}
\hline 22-Jul-11 & $1.4338 / 1.4341$ & $0.8812 / 0.8815$ & $112.39 / 112.42$ & $1.3660 / 1.3662$ & $1.6269 / 1.6270$ & $0.9517 / 0.9518$ & $78.50 / 78.52$ & $127.71 / 127.76$ \\
\hline
\end{tabular} \begin{tabular}{|l|l|l|l|l|l|l|l|l|l|}
\hline 25-Jul-11 & $1.4387 / 1.4391$ & $0.8821 / 0.8824$ & $112.55 / 112.58$ & $1.3607 / 1.3612$ & $1.6307 / 1.6310$ & $0.9446 / 0.9449$ & $78.22 / 78.25$ & $127.55 / 127.61$ \\
\hline
\end{tabular} \begin{tabular}{|l|l|l|l|l|l|l|l|l|}
\hline 26-Jul-11 & $1.4515 / 1.4518$ & $0.8843 / 0.8846$ & $113.08 / 113.11$ & $1.3611 / 1.3615$ & $1.6412 / 1.6415$ & $0.9428 / 0.9431$ & $77.90 / 77.93$ & $127.84 / 128.90$ \\
\hline
\end{tabular} \begin{tabular}{|l|l|l|l|l|l|l|l|l|l|}
\hline 27-Jul-11 & $1.4441 / 1.4444$ & $0.8815 / 0.8818$ & $112.12 / 112.18$ & $1.3626 / 1.3629$ & $1.6385 / 1.6388$ & $0.9444 / 0.9447$ & $77.25 / 77.30$ & $127.51 / 127.56$ \\
\hline
\end{tabular}

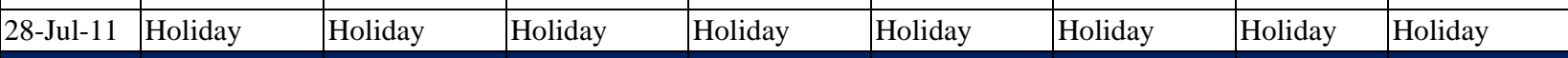

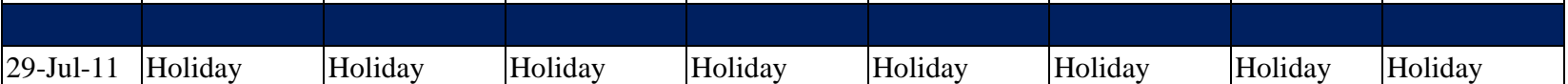
\begin{tabular}{|l|l|l|l|l|l|l|l|l|l|}
\hline 1-Aug-11 & $1.4240 / 1.4243$ & $0.8744 / 0.8747$ & $109.95 / 109.98$ & $1.3710 / 1.3713$ & $1.6283 / 1.6286$ & $0.9568 / 0.9571$ & $77.21 / 77.23$ & $125.72 / 125.76$ \\
\hline
\end{tabular} \begin{tabular}{|l|l|l|l|l|l|l|l|l|l|}
\hline 2-Aug-11 & $1.4185 / 1.4188$ & $0.8709 / 0.8712$ & $109.42 / 109.45$ & $1.3622 / 1.3625$ & $1.6286 / 1.6289$ & $0.9600 / 0.9603$ & $77.12 / 77.15$ & $125.62 / 125.66$ \\
\hline
\end{tabular} \begin{tabular}{|l|l|l|l|l|l|l|l|l|}
\hline 3-Aug-11 & $1.4314 / 1.4317$ & $0.8718 / 0.8721$ & $110.06 / 110.09$ & $1.3728 / 1.3730$ & $1.6415 / 1.6418$ & $0.9634 / 0.9637$ & $76.88 / 76.91$ & $126.21 / 126.26$ \\
\hline
\end{tabular} \begin{tabular}{|l|l|l|l|l|l|l|l|l|}
\hline 4-Aug-11 & $1.4133 / 1.4136$ & $0.8684 / 0.8687$ & $110.06 / 110.09$ & $1.3832 / 1.3835$ & $1.6271 / 1.6274$ & $0.9780 / 0.9783$ & $78.92 / 78.95$ & $128.41 / 128.47$ \\
\hline
\end{tabular} \begin{tabular}{|l|l|l|l|l|l|l|l|l|}
\hline & & & & & \\
\hline
\end{tabular} \begin{tabular}{|l|l|l|l|l|l|l|l|l|}
\hline 5-Aug-11 & $1.4288 / 1.4291$ & $0.8726 / 0.8729$ & $112.08 / 112.11$ & $1.3903 / 1.3905$ & $1.6371 / 1.6374$ & $0.9783 / 0.9786$ & $78.43 / 78.46$ & $128.39 / 128.45$ \\
\hline
\end{tabular} \begin{tabular}{|l|l|l|l|l|l|l|l|l|}
\hline 8-Aug-11 & $1.4203 / 1.4206$ & $0.8682 / 0.8685$ & $110.39 / 110.42$ & $1.4032 / 1.4035$ & $1.6356 / 1.6359$ & $0.9912 / 0.9915$ & $77.71 / 77.74$ & $127.07 / 127.13$ \\
\hline
\end{tabular} \begin{tabular}{|l|l|l|l|l|l|l|l|l|}
\hline 9-Aug-11 & $1.4228 / 1.4231$ & $0.8770 / 0.8773$ & $109.33 / 109.36$ & $1.4132 / 1.4136$ & $1.6221 / 1.6224$ & $0.9940 / 0.9943$ & $76.83 / 76.86$ & $124.63 / 124.69$ \\
\hline
\end{tabular} \begin{tabular}{|l|l|l|l|l|l|l|l|l|l|}
\hline 10-Aug-11 & $1.4229 / 1.4232$ & $0.8802 / 0.8805$ & $109.23 / 109.26$ & $1.4139 / 1.4142$ & $1.6164 / 1.6167$ & $0.9887 / 0.9891$ & $76.75 / 76.78$ & $124.06 / 124.12$ \\
\hline
\end{tabular} \begin{tabular}{|l|l|l|l|l|l|l|l|l|l|}
\hline 11-Aug-11 & $1.4213 / 1.4216$ & $0.8767 / 0.8770$ & $109.22 / 109.25$ & $1.4083 / 1.4085$ & $1.6208 / 1.6211$ & $0.9894 / 0.9897$ & $76.84 / 76.87$ & $124.54 / 124.60$ \\
\hline
\end{tabular} \begin{tabular}{|l|l|l|l|l|l|l|l|l|}
\hline 12-Aug-11 & $1.4234 / 1.4237$ & $0.8744 / 0.8747$ & $109.32 / 109.35$ & $1.4065 / 1.4067$ & $1.6277 / 1.6280$ & $0.9913 / 0.9916$ & $76.79 / 76.82$ & $124.99 / 125.05$ \\
\hline
\end{tabular} \begin{tabular}{|l|l|l|l|l|l|l|l|l|l|}
\hline 15-Aug-11 & $1.4443 / 1.4446$ & $0.8813 / 0.8816$ & $110.87 / 110.90$ & $1.4113 / 1.4115$ & $1.6386 / 1.6389$ & $0.9817 / 0.9821$ & $76.75 / 76.78$ & $125.76 / 125.82$ \\
\hline
\end{tabular} \begin{tabular}{|l|l|l|l|l|l|l|l|l|}
\hline 16-Aug-11 & $1.4406 / 1.4409$ & $0.8751 / 0.8754$ & $110.59 / 110.62$ & $1.4157 / 1.4160$ & $1.6459 / 1.6462$ & $0.9829 / 0.9832$ & $76.75 / 76.78$ & $126.32 / 126.38$ \\
\hline
\end{tabular} \begin{tabular}{|l|l|l|l|l|l|l|l|l|l|}
\hline 17-Aug-11 & $1.4446 / 1.4449$ & $0.8721 / 0.8724$ & $110.46 / 110.49$ & $1.4160 / 1.4163$ & $1.6562 / 1.6565$ & $0.9807 / 0.9811$ & $76.46 / 76.49$ & $126.64 / 126.70$ \\
\hline
\end{tabular} \begin{tabular}{|c|c|c|c|c|c|c|c|c|}
\hline $18-A u g-11$ & $1.4329 / 1.4332$ & $0.8688 / 0.8691$ & $109.66 / 109.69$ & $1.4165 / 1.4168$ & $1.6491 / 1.6494$ & $0.9901 / 0.9904$ & $76.52 / 76.55$ & $126.19 / 126.25$ \\
\hline
\end{tabular} 
(Table A4 continued)

\begin{tabular}{|c|c|c|c|c|c|c|c|c|}
\hline \multirow{3}{*}{ DATE } & \multicolumn{8}{|c|}{ G7 CURRENCY } \\
\hline & \multicolumn{8}{|l|}{ CLOSE PRICE } \\
\hline & EUR/USD & EUR/GBP & EUR/JPY & EUR/CAD & GBP/USD & USD/CAD & USD/JPY & GBP/JPY \\
\hline 19-Aug-11 & $1.4384 / 1.4387$ & $0.8721 / 0.8724$ & $110.08 / 110.11$ & $1.4180 / 1.4183$ & $1.6489 / 1.6492$ & $0.9888 / 0.9891$ & $76.51 / 76.54$ & $126.17 / 126.23$ \\
\hline 22-Aug-11 & $1.4371 / 1.4374$ & $0.8723 / 0.8726$ & $110.29 / 110.32$ & $1.4125 / 1.4129$ & $1.6472 / 1.6475$ & $0.9888 / 0.9891$ & 76.73/76.76 & $126.39 / 126.45$ \\
\hline $23-\mathrm{Au}$ & $1.4425 / 1.4428$ & $0.8741 / 0.8744$ & $110.61 / 110.64$ & $1.4248 / 1.4252$ & $1.6501 / 1.6504$ & $0.9892 / 0.9895$ & $76.67 / 76.70$ & $126.51 / 126.57$ \\
\hline 24-Aug-11 & $1.4469 / 1.4472$ & $0.8805 / 0.8808$ & $111.00 / 111.03$ & $1.4249 / 1.4254$ & $1.6373 / 1.6376$ & $0.9884 / 0.9887$ & 76.97/77.01 & 126.09 \\
\hline 25-Aug-11 & $1.4371 / 1.4374$ & $0.8825 / 0.8828$ & 111.55 & .4210 & 6285 & $0.9862 / 0.9865$ & 77.59/77.62 & 126.39 \\
\hline 26-Aug-11 & $1.4479 / 1.4482$ & $0.8858 / 0.8861$ & $111.05 / 111.08$ & $1.4235 / 1.4239$ & $1.6342 / 1.6345$ & $0.9848 / 0.9851$ & 76.69/76.72 & $125.33 / 125.39$ \\
\hline 29-Aug-11 & $1.4528 / 1.4530$ & $0.8848 / 0.8850$ & $111.47 / 111.52$ & $1.4160 / 1.4162$ & $1.6425 / 1.6429$ & $0.9767 / 0.9769$ & $76.48 / 76.50$ & $126.18 / 126.21$ \\
\hline 30-Aug-11 & $1.4227 / 1.4229$ & $0.8810 / 0.8813$ & $110.04 / 110.08$ & $1.4110 / 1.4114$ & $1.6645 / 1.6649$ & $0.9537 / 0.9539$ & 74.64/74.68 & 124.57 \\
\hline 31-Aug-11 & $1.4444 / 1.4447$ & $0.8836 / 0.8839$ & $110.62 / 110.65$ & $1.4129 / 1.4134$ & $1.6332 / 1.6335$ & $0.9750 / 0.9754$ & $76.62 / 76.65$ & 125.13 \\
\hline 1-Sep-11 & $1.4275 / 1.4278$ & $0.8822 / 0.8825$ & $109.64 / 109.67$ & $1.3942 / 1.3946$ & $1.6178 / 1.6181$ & $0.9753 / 0.9756$ & 76.80/76.83 & $124.24 / 124.30$ \\
\hline 2-Sep-11 & $1.4186 / 1.4189$ & $0.8749 / 0.8752$ & $108.85 / 108.88$ & $1.3934 / 1.3939$ & /1.6214 & 9844 & 76.72/76.75 & 24.43 \\
\hline 5-Sep-11 & $1.4091 / 1.4094$ & $0.8753 / 0.8756$ & $108.34 / 109.37$ & $1.3922 / 1.3925$ & $1.6097 / 1.6100$ & $0.9909 / 0.9912$ & 76.87/76.90 & $123.74 / 123.80$ \\
\hline 6-Sep-11 & $1.3999 / 1.4002$ & $0.8777 / 0.8780$ & 108.60/108.63 & $1.3972 / 1.3975$ & $1.5948 / 1.5951$ & 0.9893/0.9896 & $77.57 / 77.60$ & $123.71 / 123.77$ \\
\hline 7-Sep-11 & $1.4084 / 1.4087$ & $0.8814 / 0.8817$ & $108.92 / 108.95$ & $1.3865 / 1.3869$ & $1.5976 / 1.5979$ & $0.9861 / 0.9864$ & 77.32/77.35 & $123.53 / 123.59$ \\
\hline 8-Sep-11 & $1.3901 / 1.3904$ & $0.8702 / 0.8705$ & $107.67 / 107.70$ & $1.3814 / 1.3819$ & $1.5973 / 1.5976$ & $0.9885 / 0.9888$ & 77.44/77.47 & $123.69 / 123.75$ \\
\hline 9-Sep-11 & $1.3659 / 1.3662$ & $0.8606 / 0.8609$ & $105.73 / 105.76$ & $1.3706 / 1.3710$ & $1.5869 / 1.5872$ & $0.9972 / 0.9975$ & 77.40/77.43 & $122.82 / 122.88$ \\
\hline 12-Sep-11 & $1.3617 / 1.3619$ & $0.8611 / 0.8615$ & $105.05 / 105.08$ & $1.3669 / 1.3672$ & $1.5810 / 1.5813$ & $0.9965 / 0.9967$ & $77.26 / 77.30$ & $122.18 / 122.22$ \\
\hline 13-Sep-11 & $1.3729 / 1.3732$ & $0.8678 / 0.8681$ & $105.49 / 105.52$ & $1.3532 / 1.3538$ & $1.5819 / 1.5822$ & $0.9872 / 0.9875$ & 76.83/76.86 & $121.53 / 121.59$ \\
\hline 14-Sep-11 & $1.3752 / 1.3755$ & $0.8715 / 0.8718$ & $105.43 / 105.46$ & $1.3580 / 1.3584$ & $1.5777 / 1.5780$ & $0.9898 / 0.9901$ & 76.65/76.68 & $120.94 / 121.00$ \\
\hline 15-Sep-11 & $1.3872 / 1.3875$ & $0.8766 / 0.8770$ & $106.65 / 106.69$ & $1.3618 / 1.3624$ & $1.5851 / 1.5855$ & $0.9856 / 0.9860$ & 76.63/76.66 & $121.42 / 121.46$ \\
\hline 16-Sep-11 & $1.3808 / 1.3811$ & $0.8733 / 0.8736$ & $105.78 / 105.79$ & $1.3542 / 1.3546$ & $1.5818 / 1.5820$ & $0.9842 / 0.9845$ & 76.69/76.72 & $121.29 / 121.32$ \\
\hline 19-Sep-11 & $1.3681 / 1.3684$ & $0.8713 / 0.8716$ & $104.62 / 104.65$ & $1.3140 / 1.3417$ & $1.5697 / 1.5700$ & $0.9897 / 0.9900$ & $76.47 / 76.50$ & $120.03 / 120.09$ \\
\hline 20-Sep-11 & $1.3673 / 1.3676$ & $0.8773 / 0.8776$ & $104.78 / 104.81$ & $1.3582 / 1.3586$ & $1.5583 / 1.5586$ & $1.0034 / 1.0037$ & $76.62 / 76.65$ & $119.40 / 119.46$ \\
\hline 21-Sep-11 & $1.3673 / 1.3676$ & $0.8773 / 0.8776$ & $104.78 / 104.81$ & $1.3582 / 1.3586$ & $1.5583 / 1.5586$ & $1.0034 / 1.0037$ & $76.62 / 76.65$ & $119.40 / 119.46$ \\
\hline 22-Sep-11 & $1.3453 / 1.3456$ & $0.8767 / 0.8770$ & $102.75 / 102.78$ & $1.3883 / 1.3886$ & $1.5343 / 1.5346$ & $1.0298 / 1.0301$ & 76.36/76.39 & $117.15 / 117.21$ \\
\hline
\end{tabular}

Note. Source: Several platorms. 